\title{
Toward a Political Anthropology of Mission Sound: Paraguay in the 17th and 18th Centuries ${ }^{1}$
}

\section{GUILLERMO WILDE ${ }^{2}$}

\section{Translated from the Spanish by Eric Ederer}

Any consideration of pre-Enlightenment art, particularly music, presents similar difficulties to taking on any of the so-called "aesthetic experiences" of non-Western societies. The globalizing concept of "aesthetics" inevitably becomes entangled with other notions of greater historical and ideological charge that configure a contemporary worldview-artistic individuality, creative will, and "the work of art," among others. Such notions presuppose the independence of the "aesthetic phenomenon" from its social uses and ignore cultural and political factors. Beginning with the modern secular era, these phenomena have acquired a status that is ontologically and methodologically differentiated from other spheres of social life. They are analytically fragmented into diverse aesthetic manifestations (music, painting, sculpture, theater, etc.) and are treated separately by different disciplines that privilege formal and technical attributes. As a result, their integral relation to culture is lost.

The problem becomes especially complicated when we approach an environment as socioculturally diverse as the Latin American colonial world, where such manifestations express conflicts and negotiations between European traditions and local cultures. Historiographic projects have tended to emphasize the more picturesque or anecdotal aspects of the colonial experience, omitting, on the one hand, critical analysis of the socio-cultural bases of such conflicts and their symbolic negotiations, and, on the other, analyses of their multiple hegemonic and counter-hegemonic political uses. With a few exceptions having to do with imagery and music, the search has been mainly centered on the analysis of works (the determination of a "repertoire") and the search for original authors. As a result, a modern bias has been imposed upon the worldview of that era. ${ }^{3}$

The preoccupation with authorship, repertoire, and works finds its roots in romanticism and thus postdates the period under consideration. As demonstrated in a few recent studies on colonial music, notions of "the author" and "the work" have been impediments to a clear understanding of music of the colonial era. The relationship between the concepts of "work" and "repertoire" is barely relevant, since musical products were then conceived in ways that were open, flexible, plural, and fluid. This makes it difficult to apply the kind of strict classification schemes we use for other periods. In colonial musical products, the "author function" as we understand it today was not present. The musical texts, for the most part anonymous, possessed a religious functionality: the individuality of the

1 This work was completed with the support of the National Council of Scientific and Technical Research (CONICET) and the National Agency for the Promotion of Science (Argentina).

2 CONICET, Anthropological Sciences Institute, School of Philosophy and Letters, University of Buenos Aires.

3 Piotr Nawroot, Indígenas y Cultura Musical De Las Reducciones Fesuíticas. Guaraníes, Chiquitos, Moxos. (Bolivia: Editorial Verbo Divino, 2000); Leonardo Waisman, "La contribución indígena a la música misional en Mojos (Bolivia)," Memoria Americana, Cuadernos de Etnohistoria 12 (2004): 11-38. 


\section{Music and Politics Summer 2007}

composers was dissolved, while important "extramusical" meanings accrued in multiple ceremonial and religious contexts. ${ }^{4}$

The Jesuit missions among the Guaraní and Chiquito peoples, who lived along the borders that separate present-day Argentina, Brazil, and Paraguay, were no exception. We know that the "repertoire" was managed pragmatically, selection of music being a function of availability, the discretion of mission authorities, and accessibility to indigenous musicians. It is true that important features in the works of Jesuits Domenico Zipoli and Martin Schmid provide clues about local compositional modalities and concrete aesthetics, at least for certain periods. But the sources are not sufficient to establish the existence of indigenous composers with a style of their own. In terms of specific genres-mass, motet, dances, and others-the information is quite fragmentary and lacks detail. The most important Jesuit reports provide very general descriptions that prevent the formation of clear ideas regarding local variation.

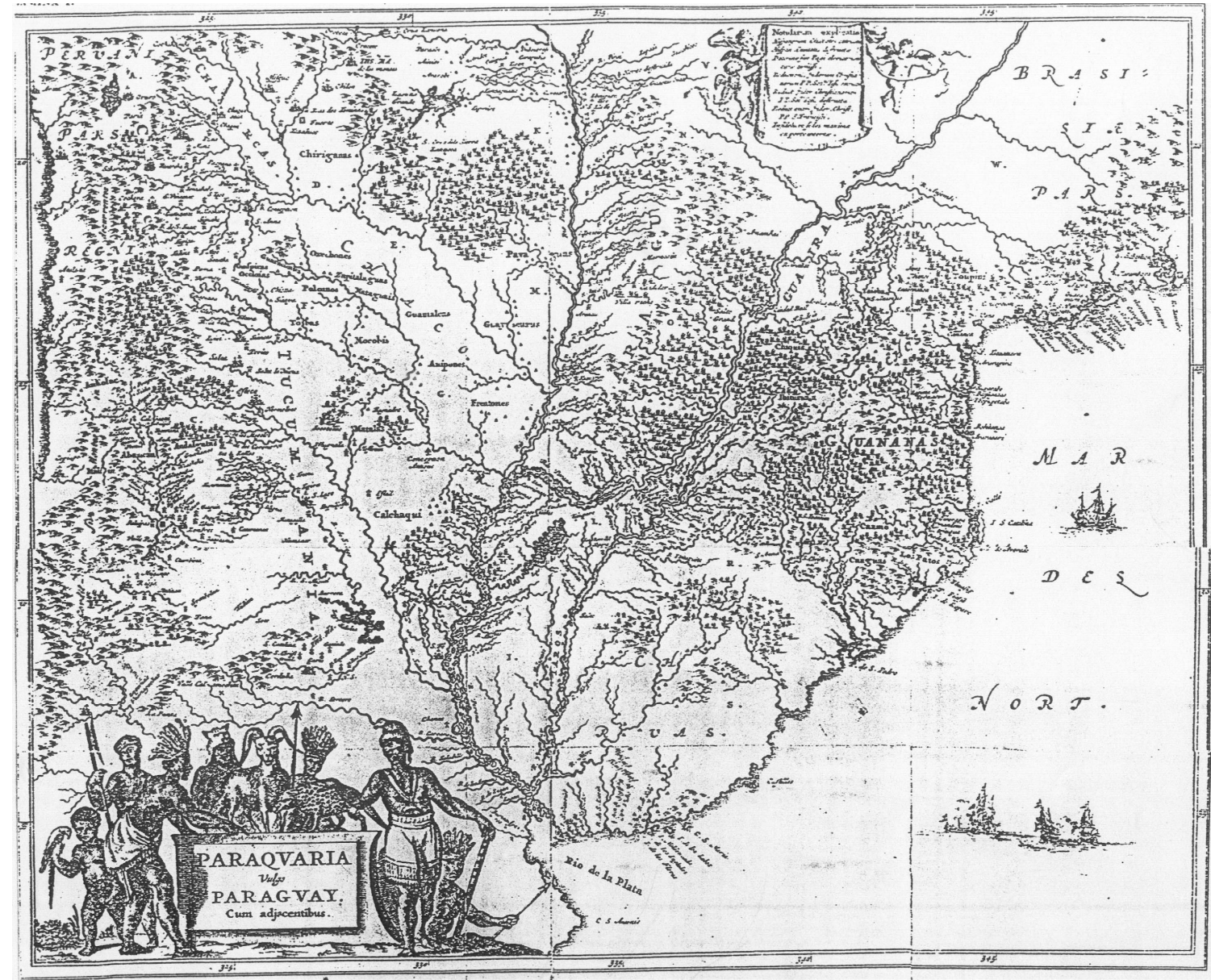

Figure 1. "Paraquaria Vulgo Paraguay cum adjacentibus. Joannes Blaeu Atlas Maior." (Amsterdam 1662). Published by: FURLONG, Guillerrno 1936 Cartografía jesuítica del Río de la Plata. Buenos Aires. Publicaciones del Instituto de Investigaciones históricas, Nro. LXXI. Facultad de Filosofía y Letras. , Lamina III, n. 06 do Catálogo, pp.26-30.

4 Bernardo Illari, "Un Laudate Pueri Como Antiobra (Acerca De La Invención De La Música Jesuítica De Chiquitos)," in Música Barroca Del Chiquitos Fesuítico. Trabajos Leídos En El Encuentro De Musicólogos (Santa Cruz de la Sierra, 1998); Leonardo Waisman, “¿Cómo Escuchar Música Colonial Latinoamericana?” Música e Investigación 1, no. 2 (1998): 99-107. 
Now, if our modern vision is not appropriate for understanding music of the colonial era, how shall we approach the sonic experiences of the past? What are the characteristics of the indigenous musical experience in missionary regions of Paraguay during the $17^{\text {th }}$ and $18^{\text {th }}$ centuries?

In this article I will explore a few ways to respond to these questions. In the first section, I discuss analytical models for the "sonic experience" in the missionary regions, putting special emphasis on what such models reveal about the native categories that define the limits of the sonic world. I continue by describing concrete uses of sound in the daily routine and rituals of the missions, showing how it served as a hegemonic mechanism that reinforced regimes of temporality and corporality. In the third section I refer to what can be called "counter-hegemonic uses of sound"-that is, those instances in which sound is openly linked to indigenous acts of resistance. Finally, I conclude by presenting some considerations about ambiguous or hybrid zones, in which sound is used as a means of negotiation between Jesuit authorities and the indigenous population.

TREINTA PUEBLOS DE MISIONES JESUÍTICO-GUARANÍES

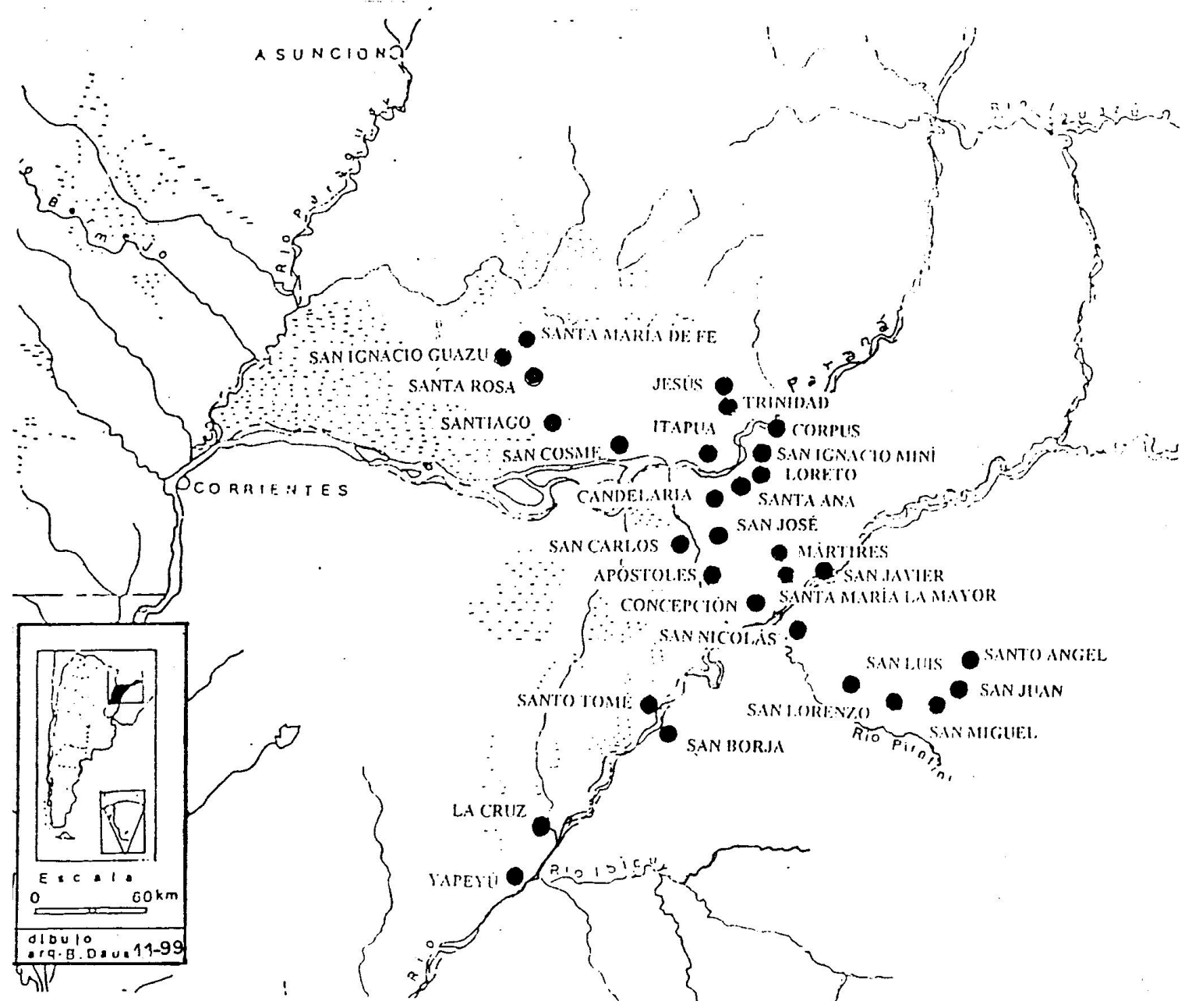

Figure 2. Map of the thirty jesuít missions of Guarani, Paraguay (1609-1768), (author: Blanca Daus/Ethnohistory Program/UBA). 


\section{Sonic Clues in Colonial Documents}

Understanding the music of the past, particularly from the colonial period in the Americas, presents a double problem. The first part of the problem is well known and holds for any manifestation that could be classified as "aesthetic" in different socio-cultural and historical spaces. This sort of problem arises at the representational level: transposing the register of one experience inscribed on the plane of fleeting corporeal and gestural sensations and emotions to the linguistic register in order to make that experience intelligible in some way. In the case of the lost sonic experience, primary source documents might provide us with some clues that would allow us to understand the meaning of that experience as lived by the actors at the time. Such meaning depends on a socio-cultural context-or on a historical constellation, to use a term favored by Adorno-that also must be reconstructed from traces that are found in the same documents. This leads to the second part of the problem, which comes into play at the methodological level: the historical constellation is fundamentally alien to the modern framework with which we ourselves operate.

The fundamental anthropological challenge thus consists of understanding not only the artifacts and ideas (in this case sonic) but also the sensibility that produces and makes sense of them. This mandates an inquiry that, paradoxically, moves beyond the aesthetic. ${ }^{5}$ In any such operation of transposition we are presented with a dilemma: something on the order of "the real" always escapes conceptualization, as though meaning were being drained away. As Lévi-Strauss argues, the relationship between musical structures and words (and thus meaning) is open-ended in a way that is comparable to the relationship between the structure of myth and sound. ${ }^{6}$

With respect to the South American missionary regions, discussions of recent years have been marked by a determined search for native authors in an attempt to evaluate indigenous creative capacity. But if such a search is laudable from an ideological point of view, it is nonetheless inconsistent with the information available in the sources. Moreover, it does not seem to be truly relevant for understanding the concrete musical dynamic of the era in the sense of bringing us closer to a native point of view about sonic experience. Various methods have been attempted in order to overcome this modern bias.

One of them, outlined recently by Bernardo Illari, involves a model of exploration and analysis of missionary sound and its associations with the construction of identities. Illari suggests moving the focus of research from the musical text to the field of interpretation or the audible result of practice, which is the dimension in which indigenous agency appears best to express itself. Illari employs the category of the "sonic type," understood as the integrated features of sound produced by a human group defined at a particular moment in its history. It is possible to describe these "types" by identifying a series of characteristics. Thus the sonic type of a missionary "Indigenous-Jesuit culture" could be defined by describing: a) the instrumental and vocal forces used to interpret a work, b) the techniques of vocal production and the ways instruments are played, c) the texture of the music, d) the

5 Clifford Geertz, Conocimiento Local (Barcelona: Gedisa, 1994).

6 Levi-Strauss compares the structure of myth, music, and language by means of the graphic of a triangle, the corners (vertexes) of which are labeled word, sound, and phrase. He maintains that the structure of myth and music are similar in that both leave one of the corners open: myth leaves sound open and music leaves word open. By contrast, language closes all three corners. Claude Lévi-Strauss, Mito y significado (Buenos Aires. Alianza, 1986). 
use of dynamics, e) varieties of ornamentation, and f) the approach to rhythm and character. If this approach appears a bit schematic and its reference to "culture" questionable, it still seems effective for attempting a sonic reconstruction, village by village, that allows us to determine local particularities within the broad mission context. ${ }^{7}$ At the same time, this model can help us to establish interpretations not only of sound production but also of the reception of European music among the indigenous peoples. ${ }^{8}$

Another possible analytical approach is that which I am presenting here. It consists of placing the sonic experiences in a broader tapestry of ritual and daily practices, and not isolating them in a musical domain. ${ }^{9}$ In my judgment, to speak of "ritualized sound" instead of "music" opens the analysis to the possibility of considering the political uses made of those sounds in particular circumstances. It also facilitates the reconstruction of the indigenous conceptualizations in play, which were generally linked to religious and social practices. ${ }^{10}$

This approach begins with the premise that the native populations possessed categories and "theories" for defining and conceptualizing sonic practices, even though these are very different in character from the ones familiar today. We cannot make use of the objectivist perspective of the modern observer, which emphasizes formal properties and stylistic features. The perspective of the native populations stresses the subjective since it refers concretely to the modes of employing sonic practice, the privilege of owning or specializing in them, the most propitious moments for deploying them, their nature, name, and origin, and their value and associations with other practices and objects. ${ }^{11}$ These conceptual categories are effected in certain ritual or daily circumstances, for which reason they can neither be understood strictly as "musical theories" nor as "aesthetic theories."

However, it is not precisely this subjective vision of the indigenous actors that is the first to manifest itself in the missionary sources. On the contrary, what emerge immediately are the uses of sonic experience for political hegemonic purposes, for the slow, subtle, and gradual imposition of a colonial order on groups that previously had had little contact with the Spanish. Anything we learn about indigenous sonic conceptualizations from these sources is distorted through the Jesuit voice, which translates, selects, elides, and emphasizes. But Jesuit writings do offer some clues. For example, Jesuit Ruiz de Montoya, in his linguistic writings, dedicates an important section to the terms pú and

7 Bernardo Illari, "El Sonido De La Misión: Práctica de Ejecución e Identidad en las reducciones de la Provincia Del Paraguay," in Música colonial Iberoamericana: interpretaciones en torno a la práctica de ejecución y ejecución de la práctica, ed. Victor Rondon, Actas del V Encuentro simposio internacional de musicología, V Festival Internacional de Música renacentista y barroca americana "Misiones de Chiquitos," (Santa Cruz de la Sierra: APAC, 2004). Leonard Waisman advances a similar argument in his recent article, "La contribución indígena a la música misional en Mojos (Bolivia)," Memoria Americana, Cuadernos de Etnohistoria 12: 11-38.

8 In fact, looking at the Jesuit sources it is possible to establish that European styles and composers were imported into the mission environment. We know, for example, that due to the activities of Anton Sepp composers like Johann Heinrich Schmelzer and Heinrich Ignaz Biber-whose music has circulated on a variety of recordings in recent years-or the less well-known Johann Melchor Gletle and Johann Kaspar Kerl were introduced into the mission environment (Andriotti 1999). For a musical example, please see the link at the conclusion of this article.

9 Guillermo Wilde, "El ritual como vehículo de experiencias sonoras indígenas en las doctrinas jesuíticas del Paraguay (1609-1768)," in Música colonial Iberoamericana: interpretaciones en torno a la práctica de ejecución y ejecución de la práctica, ed. Victor Rondon (Santa Cruz de la Sierra: APAC, 2004).

10 See also Guillermo Wilde, "La actitud guaraní ante la expulsión de los jesuitas: Ritualidad, Reciprocidad y Espacio Social," Memoria Americana, Cuadernos de Etnohistoria 8 (1999): 141-172; Guillermo Wilde, "Poderes del ritual y rituales del poder: un análisis de las celebraciones en los pueblos jesuíticos de guaraníes," Revista Española de Antropología Americana 33 (2003): 203-229.

11 Geertz, 120. 
ndú, in Guaraní "noise" or "the sound of a thing."12 De Montoya's work reveals that "the sonic" is more appropriate for defining the indigenous experience than "the musical” inasmuch as the Guaraní notion of sound is linked to a realm that encompasses more human practices and actions. ${ }^{13}$

What then are the various daily and ritual uses made of sound in the missionary regions? Before taking up this subject it is necessary to make a brief assessment of some of the central aspects of the mentality that inspired the imposition of symbolic practices and Christian rituals in the missionary villages. This mentality is shaped by the baroque conception of ritual, which is characteristic of the socalled Ancien Régime. It is worth considering not only for the insights it provides on the efficacy of the activities of the Jesuit missionaries-the vehicle of a determined political and symbolic apparatusbut also, and above all, to reveal the concepts of society and subjectivity that underlie Jesuit actions among the indigenous people of the region. The Ancien Régime framework was behind the radical opposition of the Jesuits (expressed at least in their discourse) to the indigenous religious traditions they encountered upon their arrival and which they tried to eliminate.

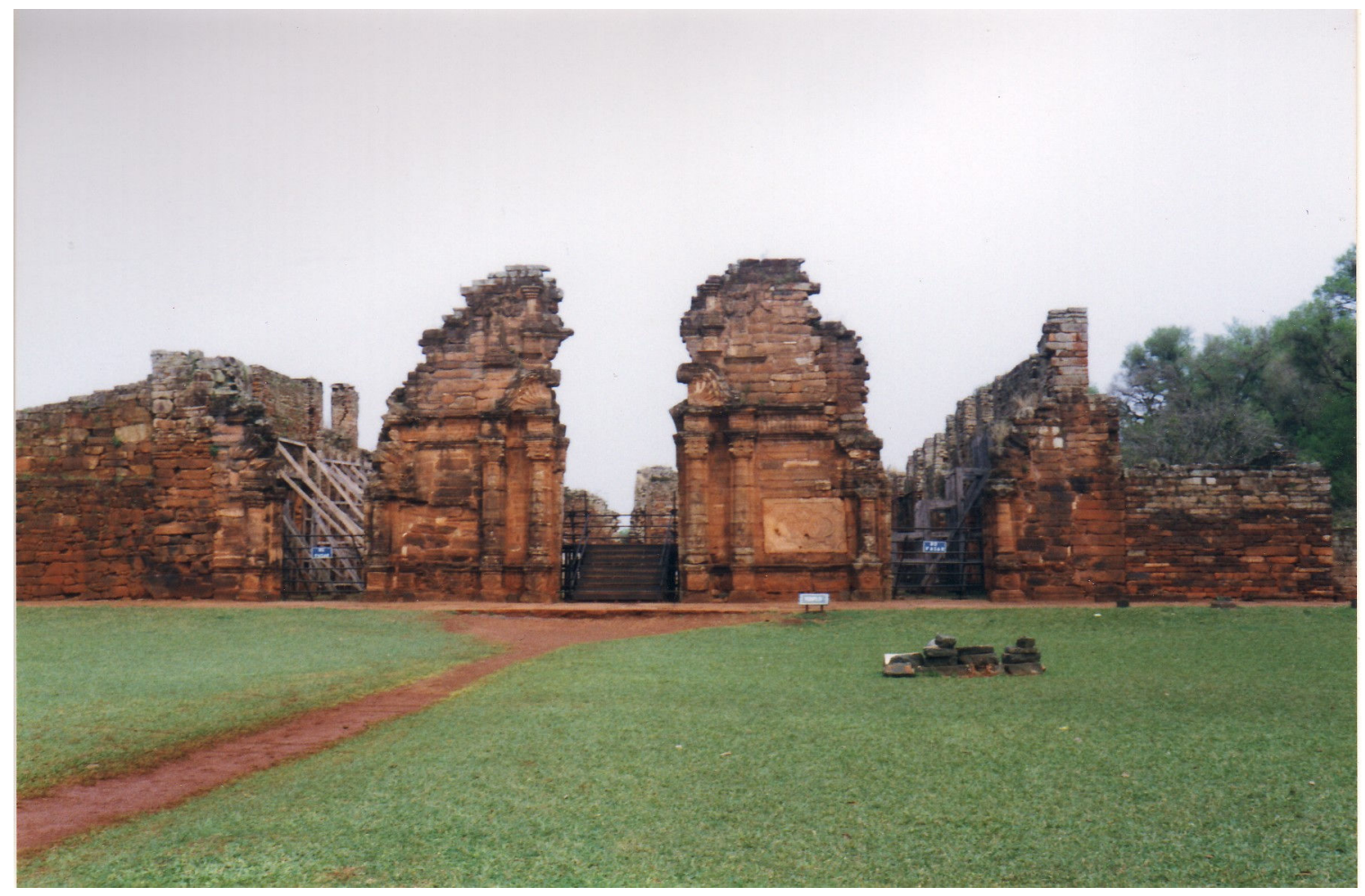

Figure 3. Village of San Ignacio Miní, view of the entrance of the church from the plaza, Misiones, Argentina (author's photo).

12 In comparison, the place assigned to the word "music" is relatively small, which may have been a consequence of it having less practical function: "Music: mboraheî. Porahê̂. Indian Music: Guahú. Womens' music: ñeengaraí. Musician: Mburahey tára. Skillful musician: Mborahê̂ rehe ecatúbae. Mborahei tara ecatú. Proquâní poraheí rehé" (Antonio Ruiz de Montoya, Arte, Bocabulario, Tesoro y Catecismo de la Lengua Guarani [Leipzig: Teubner, 1876], 104). This does not negate the appreciation that later Jesuits like Peramás, inspired by Plato, had for the pedagogical and civilizing function of music. For them, music served to cultivate a righteous temperament and maintain equilibrium amongst the citizens of a community (José Manuel Peramás, La república de Platón y los guaraníes [Buenos Aires: Emecé Editores, 1946]).

13 Wilde (2004), "El ritual como vehículo de experiencias sonoras indígenas en las doctrinas jesuíticos del Paraguay." 


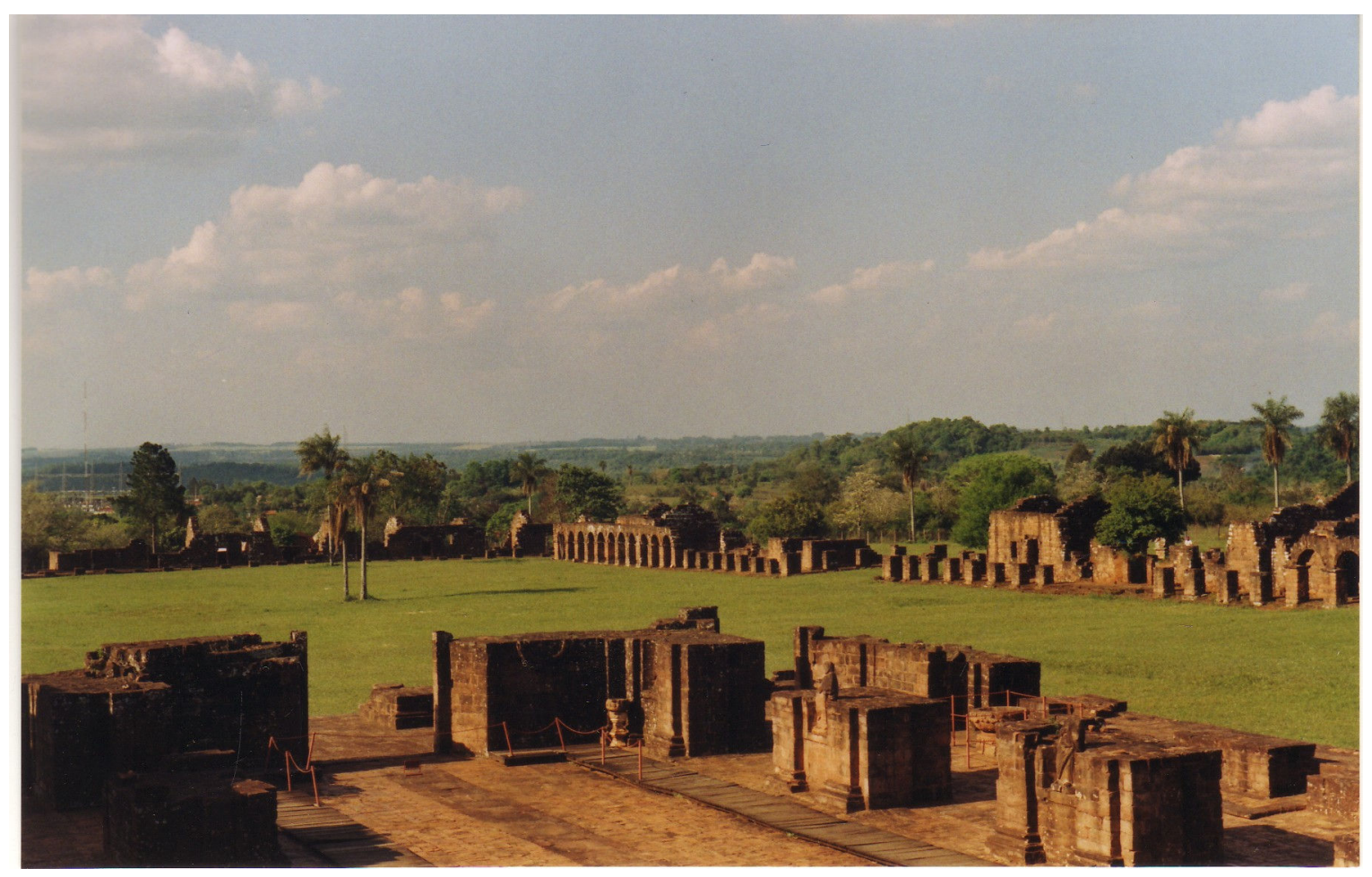

Figure 4. Reducción de Santísima Trinidad, Paraguay (author’s photo).

\section{Music, Power, and Civility in the Ancien Régime}

Even though reference to a mentality of the Ancien Régime is overly simplistic, a brief explication of certain predominant features of the political philosophy of the era makes possible an understanding of the ideology that informed the intellectuals and religious men who arrived in South America, and whose agenda it was to expand Iberian religious and socio-cultural values. The following description is based on the works of Antonio Manuel Hespanha concerning juridical law of the continental European Ancien Régime.

In the treatises of the era, politics was understood as the correct exercise of life in the city, which is to say an instrument at the service of the common good. The juridical terminology of the times abounds with concepts like affectio for explaining the nature of the social order. According to the paradigm formalized by Saint Thomas, there existed necessary links between the things that comprised the order-links that were maintained by love or some similar affect. The view held by the intellectuals of the day was that objects of the world tended naturally toward order by means of a force, an affect or love of order intrinsic to those objects themselves. This love was, in the first and last instance, a love for the common good, the glue of human societies. Thus creation consisted of an organic network of sympathies. This was the basis of the link between citizens of the Republic, beyond the hierarchies and inequalities intrinsic to the order. ${ }^{14}$ All beings and things collaborated in

14 "After underlining that all creatures — each in its way (i.e., in accord with the love of which it is capable) - loves God as Order and Totality, apply the same idea to the political world, seeing in this political love (amor, affectus, amicitia), in this love of the common good, the ties that unite the citizens in a Republic: 'This also becomes patent in the political virtues, according to which the citizens sustain the common good with the dispensation of the appropriate things and persons"” 
the eschatological destiny of the world. Thus "subordination" did not represent a lesser dignity but rather a specific place in the order, which allotted to each position obligations and rights with a natural basis. ${ }^{15}$

Consistent with this view, persons were not conceived as independent individuals-autonomous and possessing a will-in the way we have understood them to be since the Enlightenment. Instead they were members of collective entities, each occupying a place in the social structure, a status, or "state," to use a term very dear to jurisprudence of the era. ${ }^{16}$ It is interesting to note that the category of "person" or juridical subject could be extended even beyond that which is properly human. Given the universal character of order, everything in the world possessed rights and obligations. Angels and other supernatural beings, animals, inanimate objects, corporations, newborns and the deceased, or even God Himself-all were entitled to certain judicially protected rights. ${ }^{17}$

What place then did music and ritual occupy in this concept of order? According to Ancien Régime principles, ritual acts, in their quality of being bodily or verbal acts, were also inscribed on the natural order. They were not fantastic or metaphoric representations of order, but rather they constituted the order itself, making it visible and revitalizing its basic principles. Actions such as genuflection, the kissing of hands or face, the sexual relations within a family, removing or putting on a hat or other item of clothing, the use of words, and so many other practices both public and private, were bound up in the nature of things. They gave expression to objective positions in the natural order of society and therefore were delineated in a detailed and rigorous manner.

Musical harmony was a central property of order. Although heterogeneous, the things of creation worked together toward a common end, creating, according to the intellectuals of the time, a universal polyphony. In that era, Hespanha notes, the perfection of creation was seen as residing in the heterogeneity of things as they wove themselves together, sharing an objective as if a polyphonic texture encompassed the universe. The idea of a universal harmony was invoked through the image of

(Reproduced in Antonio Manuel Hespanha, "Las cateogrías del politico y de lo juridico en la época moderna,” Ius fugit 34 [1994-1995]: 63-100). From there, when speaking of political linkages in a Republic, Saint Thomas enumerates a long series of different affects, each one with its own nature.

15 "This idea that all beings are integrated, with equal dignity, into the divine order, without regard for the existing hierarchies, explains the very special relation between humility and dignity that dominates the social and political thought of medieval and modern Europe. The humble person should be kept in a subordinate position and under the guardianship that is allotted to him in the natural social order and in political government. But the apparent insignificance of the humble person hides a dignity equal to that of the powerful person. And, therefore, the hard discriminatory treatment in the social schema (in the order of nature, of law) is accompanied by a profound solicitude on the spiritual plane (in the plane of grace, of charity, of pity). This thought-which is expounded in the evangelical parable of the lilies of the field and is ritualized in the foot washing ceremonies-explains, alongside the drastic measures of social, juridical and political discrimination of the most humble (miserabiles personae, the poor, women, widows, orphans, rustics, indigenous Americans), the juridical protection and paternalistic solicitude of the powers that be toward them, protections that include the special guardianship of the prince for his interests, special privileges, more favorable juridical treatment (favor, for example in the matter of punishment, of proof, of presumption of innocence or of good faith)" (Ibid.).

16 For an analysis of the anthropological foundations of the notion of the individual in modern society see Louis Dumont, Essais sur l'individualisme. Une perspective anthropologique sur l'ideologie moderne (Paris: Éditions du Seuil, 1991).

17 "In these cases, the decisive judicial reality, the true juridical person, is the state, permanent, and not the individuals, transitory, that confer a face on the state any given moment. Such is the society of states (Ständesgesellschaft) characteristic of the Ancien Régime, which antecedes the current society of individuals" (Hespanha 1994-95: s/p). 
a choir of many voices or an orchestra of angels that exalted diversity and the unity of the world at the same time. ${ }^{18}$

More than a metaphor for order, the notion of harmony emulated the fundamental nature of things. Although this was taken as a given, it was not regarded as being manifestly obvious; it had to be laboriously extrapolated. Thus there existed a hermeneutics of order that could only be reached through revelation, gnosis, or observation. The world was conceived as a mirror in which each element was capable of reflecting the whole; each thing was a sign of all other things and of the order that regulated them. Music, arithmetic, and geometry were the principle fields of knowledge charged with deciphering the meaning of an order that was, above all, a political and civic order. It is no coincidence that we find, starting many centuries earlier, references to harmony and music in successive treatises dedicated to politics. ${ }^{19}$

Let us return now to our South American missionary context. An exploration of the best known Jesuit chronicles of the eighteenth century allows us to conclude that ceremony in the missions was a central vehicle for the conceptions of subjectivity and society that the Jesuits brought to America and tried to impose upon the converted indigenous populations. Their ideal of subjectivity found expression in the context of an urban life, which was conceived along the lines of the ancient notion of Polis. It is not coincidence that the Jesuit José Manuel Peramás refers to the mission of the Guaraní of Paraguay in terms explicitly drawn from Plato's Republic. This vision is probably also informed by other utopias imagined in antiquity. ${ }^{20}$

The very idea of the mission (reducción) presupposed Christian life in the city. ${ }^{21}$ Thus Peramás points out that the conversion of the indigenous populations began when they were convinced to leave their isolated huts. Under the orders of their chiefs, they grouped themselves in common settlements, thus founding "cit[ies]" in which they could help each other, "consolidating their ideas and efforts."22 Urban organization, in its regular and harmonious distribution of streets and buildings, was the

18 The idea of society organized as a polyphony can be assimilated conceptually into the concept of multi-choral society (Regarding colonial society in upper Colonial Peru, see specifically Illari, "Polychoral Culture: Cathedral Music in La Plata (Bolivia)" [PhD diss., University of Chicago, 2001]).

19 Relations between music and politics form a special chapter in the intellectual tradition of the Ancien Régime. Hespanha points out that the fifth-century philosopher Boethius, widely read throughout the Middle Ages, theorized about the sympathy between the harmony of music and the harmony of politics in his De Musica. For his part, Juan IV de Braganza, having ascended to the Portuguese throne after the revolution of 1640, was a musician and was known for applying his musical knowledge to government. The term "harmony" also appears in works such as those of António de Sousa de Macedo (1737) and Sebastião Pacheco Varela (1702). The latter suggests delivering political reports to the prince by way of numbers and musical notes (Hespanha 1994-95). On the subject of using musical terms as metaphors for political functions see also Bouza Alvarez "Dissonance dans la monarchie. Une fiction musicale de la politique baroque autour du mouvement portugais de 1640", in Recherche sur l'histoire de l'État dans le monde ibérique, ed. J.-F. Schaub (Paris: E.N.S., 1993) (Cited by Hespanha 1994-95).

20 Much has been written on the links between classical utopias. Among the more important studies are Arno Alvarez Kern, Missoes, uma utopia politica (Porto Alegre: Rio Gande do Sul, 1982) and Stellio Cro, "Empirical and Practical Utopia in Paraguay," Dieciocho 15, no. 1-2 (1992): 171-184.

21 The terms reducción, misión and doctrina were considered synonyms in common usage, although in the strict sense reducción or misión alluded to villages formed with an indigenous population in the process of conversion to Christianity. Once they had reached stability these became doctrinas or parroquias de indios. The term reducción was used more often in reference to villages located in central zones of the Spanish Empire, while the term mision was used for peripheral or frontier zones. Here the difference basically resided in the size and stability of the village (Magnus Mörner, La corona española y los foráneos en los pueblos de indios de América, [Madrid. Ediciones de Cultura Hispánica/AECI.1999]).

22 Peramás, 121. 
physical manifestation of a utopia, a "happy Christian [community]" that could maintain its vitality and coherence through religious ceremony.

Peramás emphasizes the virtues of city life, identifying them one by one and describing the ways in which the Jesuits managed to impose them in such a far-flung corner of the world as Paraguay. He mentions "moderation" and "prudence" as being among the principle qualities of civility. Following Plato, he highlights the importance of the "moderate man" who controls his appetites for fear of the law and with reason as his guide. ${ }^{23}$ As a result, he commends the values of frugality and sobriety manifest in the public meals the Guaraní held to mark certain solemn occasions. "All was done there [affirms the Jesuit] with moderation." ${ }^{24}$ Also following Plato, Peramás underscores the importance of music, dance, and the arts for reinforcing civic virtues, for contributing to the education and control of a citizenry's body and soul-or, to put it another way, to control the passions. ${ }^{25}$

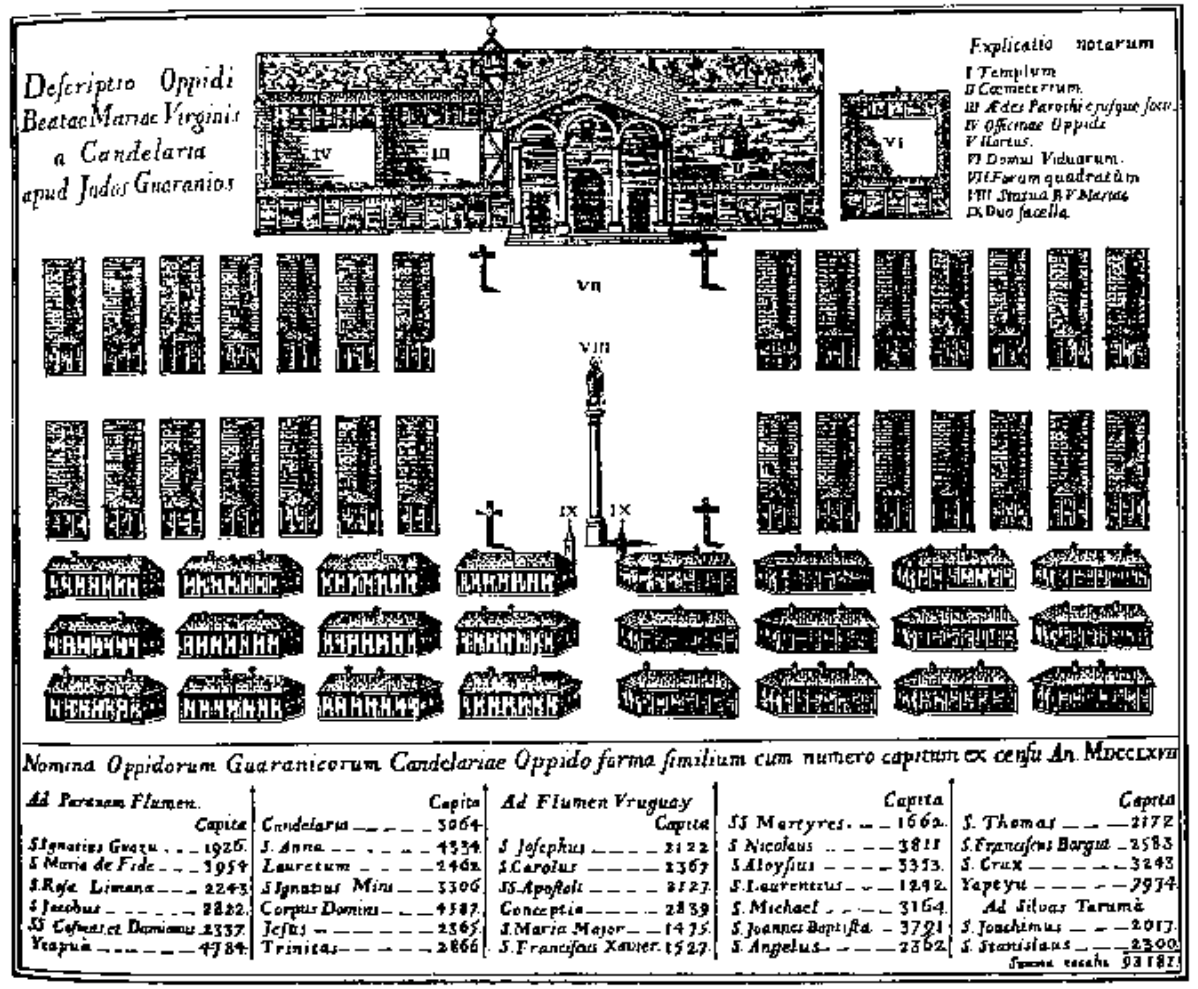

Figure 5. Plan of the village of Candelaria currently located in Misiones, Argentina (Picture from: Peramás [1791] 1946)

23 "[...] it must be brought about, in consequence, that this appetite, common to man and beast, put on the breaks and be dominated by the fear of the law and the guide of reason. All this will be achieved by those honorable censors of the public meals, whose gaze none can escape" (Ibid., 99).

24 Ibid., 100.

25 From Plato Peramás takes the idea that music is a "[...] natural instinct that has universal characteristics; there is no nation, however barbarous and lacking in culture, that in weddings, banquets and public games does not make use of music" (Peramás, 79). In relation to the Guaraní the Jesuit writes: “[...] they sang daily during the Mass, accompanied by the organ and the other instruments. In the afternoon, after the Rosary, they intoned a brief motet in honor of the Holy Sacrament and of Mary, Mother of God, to which the whole village responded. Finally the Act of Contrition was prayed. In general one can say about the music of the Guaraní that in the temple it was devoted and solemn, and disdained profane theatrical cadences or melodies (which many profane and incapable musicians have tried to introduce, for shame! into the holy precinct); and in homes and in the country it was honest and dignified, without admitting anything that could corrupt custom" (Ibid., 82). 


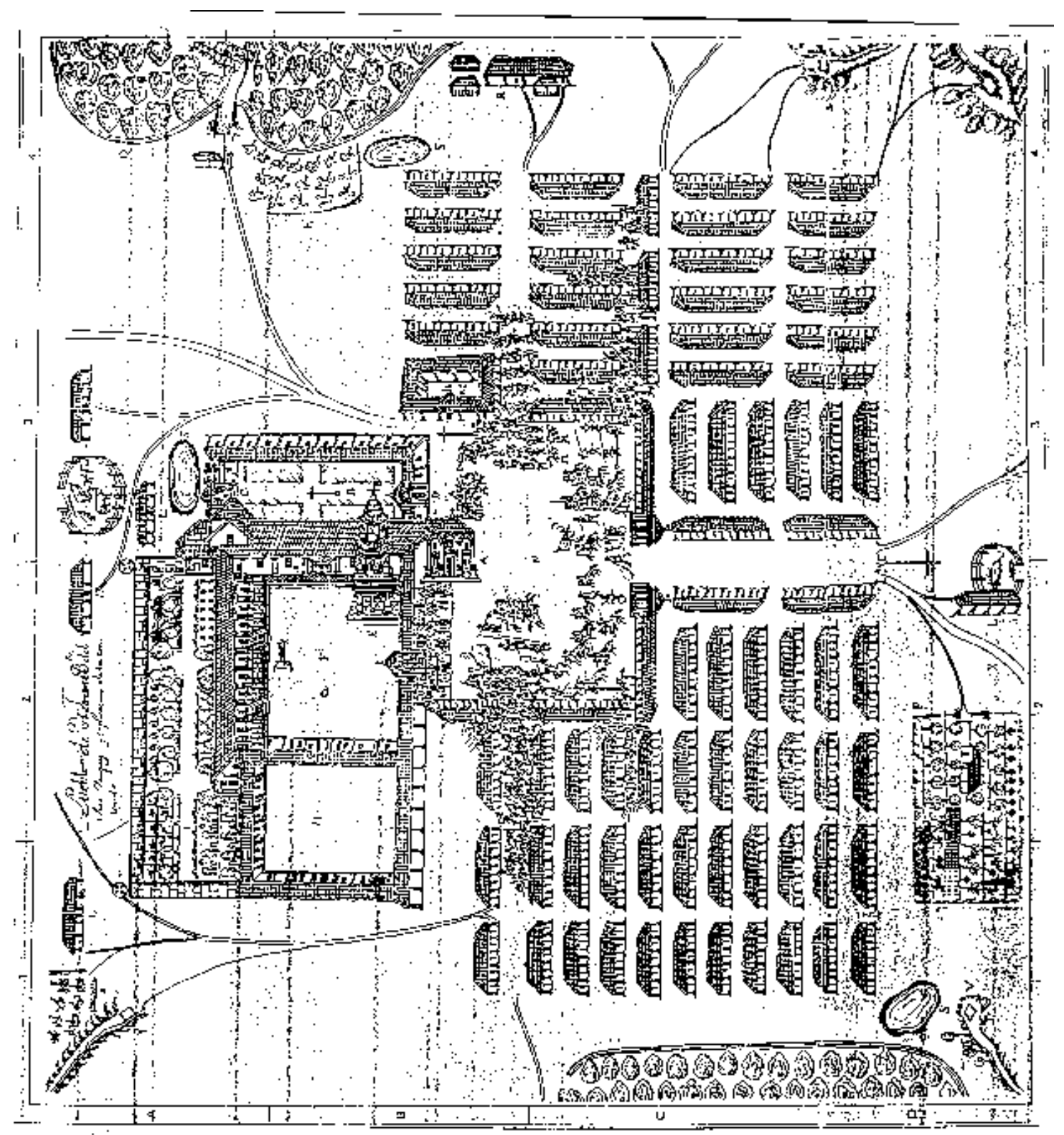

Figure 6. Celebration in the village of San Juan Bautista (ca. 1750). Picture from: Torre Revelo, José 1938 Mapas y planos referentes al Virreinato del Plata conservados en el Archivo General de Simancas. Buenos Aires [original in colors at the General Archive of Simancas, Valladolid, Spain).

In sum, music, sound, and ritual served as useful devices for imposing a traditional European subjectivity upon the indigenous peoples under direct missionary control. European socio-cultural traditions are evident in the organization of indigenous daily life according to a double disciplinary regimen of body and time. As far as the discipline of time is concerned, reports about the rational order of missionary village life are well known: the alternation of mass and labor designed to eliminate the uneven handling of productive activities. The sound of bells and drums were often used to guide the movements of the indigenous populations through the various daily activities and rituals. Jesuit 
José Cardiel notes in his Declaración de la verdad ("Declaration of Truth") that all villages possess a sundial and that a bell is rung at each part of the hour. After meals, there was conversation around the table until the bell was sounded again, signaling that it was time to gather at the church for the Holy Sacrament. In the afternoon "Vespers and Compline are rung, and at their times Matins and Lauds, and we go to confession." At four, a large bell in the mission tower was rung, calling the priests and people to gather together for catechism and subsequently the rosary. The Jesuit adds that in each tower there are between six and eight large and small bells. ${ }^{26}$ Mission Villages also made use of the sound of drums to call the boys and girls under the age of seventeen to the catechism. ${ }^{27}$

Sound also contributed to the regimentation of indigenous bodily habits and sexual behavior. Thus, for example, we know from an official of the period following the expulsion that, during the time of the Jesuits, it was the custom to beat boxes at various junctures during the night, particularly in the early morning. The object was to remind married Indians of their marital obligations, since many returned from their labors so tired that they did not maintain sexual relations with their wives, resulting in a decline of the population. ${ }^{28}$ This amusing anecdote reveals the efficacy of sound as an instrument of social control that operated daily in a naturalized manner. Here, the sound of the boxes at night is functionally equivalent to the daily ringing of bells to prompt attendance at prayers and collective labors. We are not able to give the production and playing of musical instruments the special treatment it deserves here, but it is worth pointing out that to a considerable degree instruments were used in activities oriented toward establishing a daily order governed by European values. $^{29}$

At the root of European juridical culture during the Ancien Régime was the concept of human society as part of a universal and natural order, and it was this concept that motivated the imposition of regimens of temporality and corporality. That order, established by God, predated human will, which remained subordinate to the natural tendency toward harmonic and equilibrated integration dictated by the laws of the universe. The law, which made social life possible, was in this sense an act of reason more than of will. In the missions, Jesuits inevitably attempted to impose a conception of "the civic" that was based on these ideas, silencing traditional indigenous practices that seemed antithetical to it.

26 José Cardiel, Misiones del Paraguay - Declaración de la verdad (Buenos Aires: Imprenta de Juan A. Alcina, 1900), $247-252$.

27 Juan Escandón, Carta al Padre Andrés Marcos Burriel, in Guillermo Furlong Juan Escandón y su carta a Burriel (1760). (Buenos Aires: Ediciones Theoria,1965), 88.

28 Gonzalo de Doblas, "Memoria histórica, Geográfica, política y económica sobre la Provincia de Misiones de indios guaranties," in Colección de obras y documentos relativos a la historia antigua y moderna de las Provincias del Río de la Plata, ed. Pedro de Angelis (Buenos Aires : Imprenta del Estado. 1836-1837), 50; Wilde, 2004.

29 In the village of Yapeyú, considered the most important musical center of the missions, musical instruments are mentioned along with bells, silver spurs, and shakers of various sizes. It is possible that these shakers refer to shakers or maracas like those represented in the frieze of the village of Trinidad. Sepp writes "The musicians are the most skillful: not only do some of them play all the instruments, and not just one or two like the Germans, but they also forge bells whose sound is as sonorous as the bells of Nola in Campania, they make bell clocks similar to those of Augsburg, organs, bugles, piccolos and flutes, recorders, fagottes, harps, lutes, violins, silver candelabras, suspension lamps, chalices, jewelry boxes and all that is made of gold, silver, iron, copper, tin, tin alloy and lead in the cities of Nüremberg, Vienna, Cologne, or Strasbourg. And what is more outstanding: the same man who yesterday in the iron works with hammer in hand, seeming like a robust black Vulcan forging hard iron on the anvil, is seen today embroidering, like another Arachne, with a specialized needle, the gala uniform for the sergeant-at-arms or royal standard bearer" (Anton Sepp, Fardin de flores Paracuario. [Buenos Aires: EUDEBA, 1973], 179, emphasis mine). 


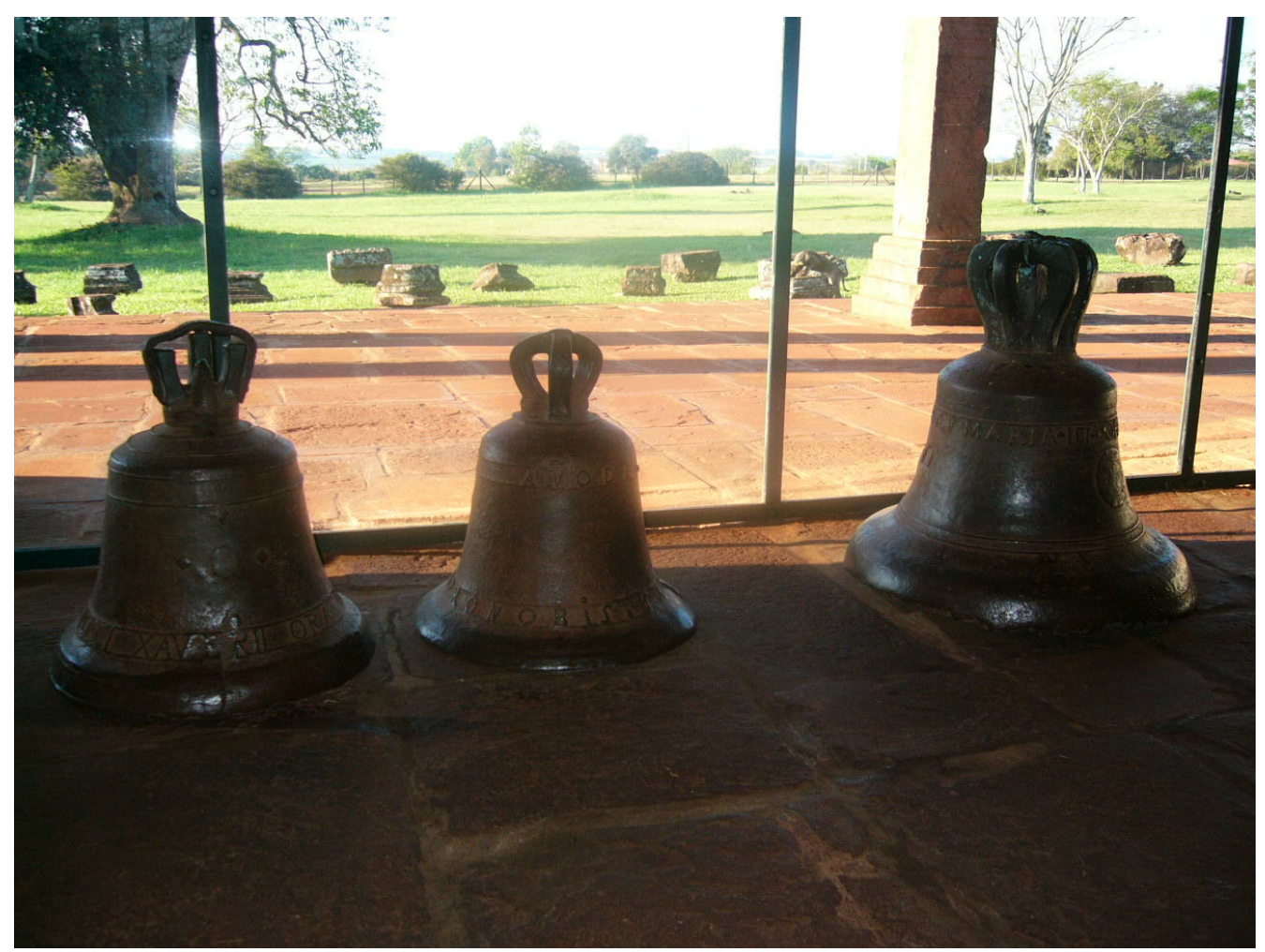

Figure 7. Different kinds of bells, village of San Miguel, Brazil (author's photo).

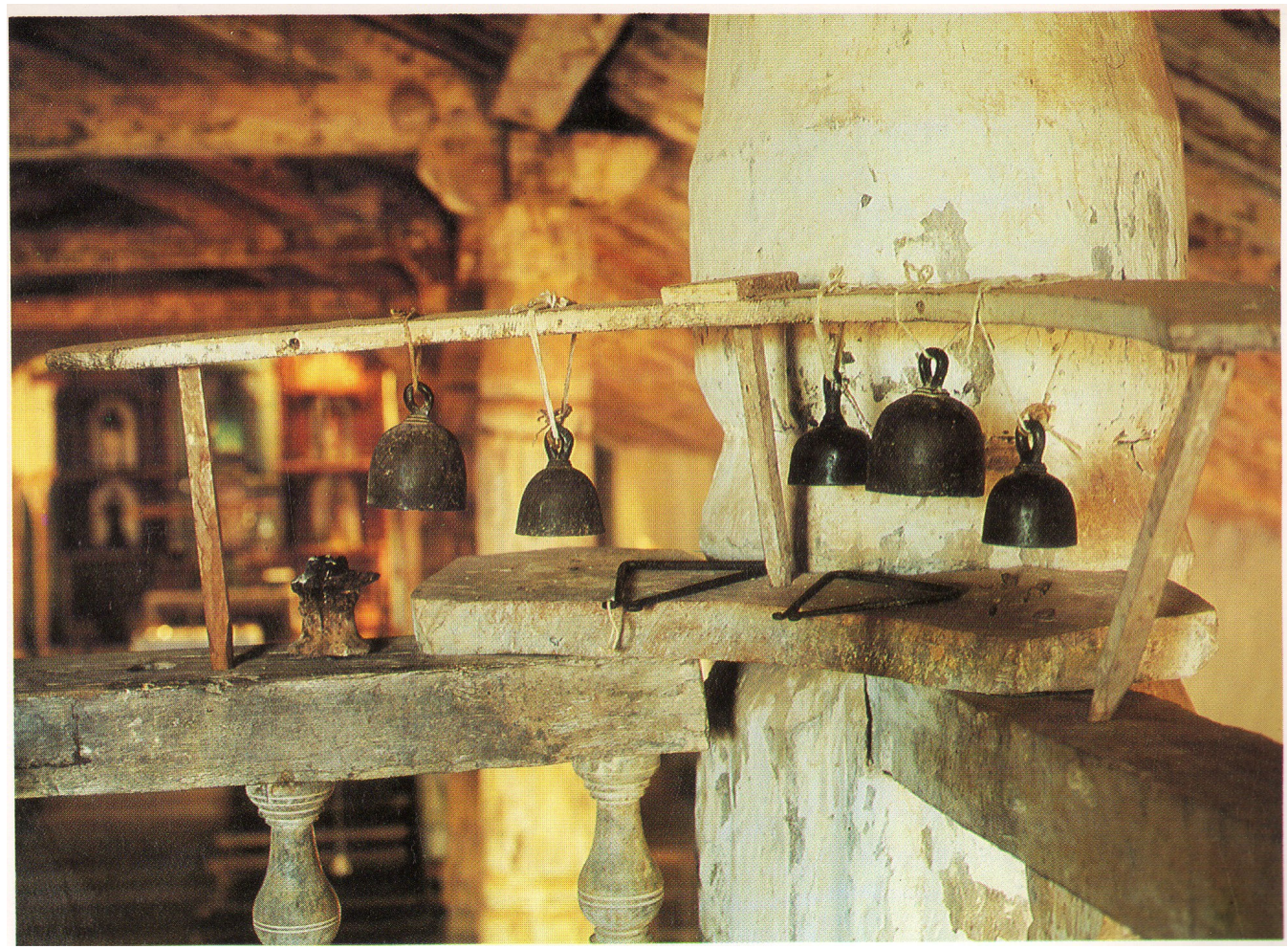

Figure 8. Small bells from the village of Santa Ana, Chiquitos region, Bolivia. Picture from: Szarán, Luis \& Jesús Ruyiz Nestosa 1999 Música en las reducciones jesuíticas de América del Sur. Colección de instrumentos de Chiquitos, Bolivia. Fundación Paracuaria, Missionsprojur S.J. Nürnberg, Centro de Estudios Paraguayos "Antonio Guasch”. Asunción 


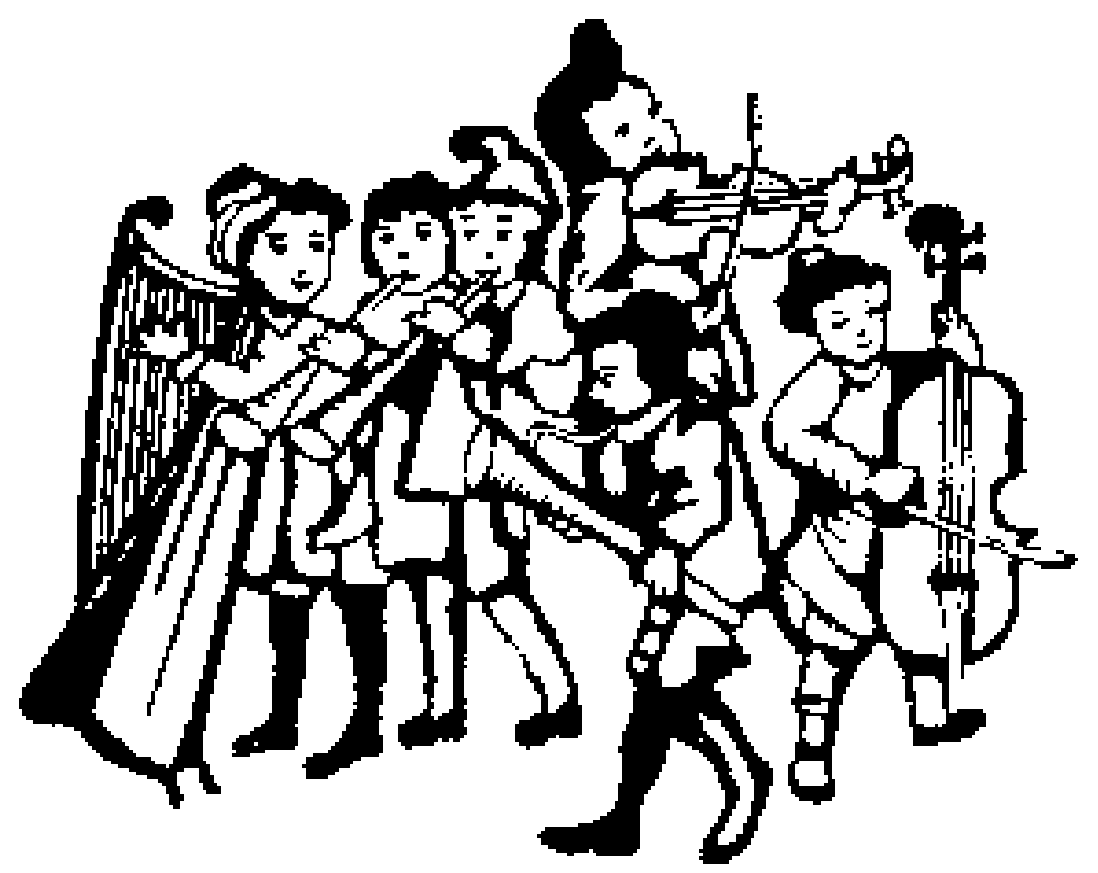

Figure 9. Mission Orchestra, detail from the plan of San Juan Bautista. General Archive of Simancas, Valladolid, Spain.

It must be kept in mind that the cited descriptions of Cardiel and Escandón are from a later period, and that the process of imposing Christian ritual practices was achieved gradually and not without resistance. It is obvious that the indigenous population did not accept these impositions in a passive manner. When they did not oppose them openly, as did occur in the period of the formation of the missions, they developed subtle ways of incorporating them into their previous customs, some of which were tolerated by mission authorities. It is useful to survey the uses of sound and indigenous ritual practices in the formative period of Guaraní missions, even though the scarcity of sources dictates that such a survey will inevitably be brief.

\section{The Sounds of Indigenous Resistance}

Upon their arrival in Paraguay, the Jesuits encountered indigenous rituals that were expressive of religious cosmologies and modes of living that were radically different from European ones. Disgracefully, practically no testimony about these rituals has been left to us, which also makes it difficult to discern the ways the Jesuits came to impose Christian ritual practices. Two issues should be kept in mind. First, the process of converting the indigenous population to Christianity was slow and it was not until the beginning of the eighteenth century that a well-defined pattern of Christian of 
ceremonies took hold. ${ }^{30}$ Surely an important period of ambiguity persisted for some time. Various early accounts are suggestive in this regard, for example the following comments by Diego Boroa in reference to the village of Santos Mártires:

They had a well rooted and barbarous custom of crying superstitiously and immoderately over their deceased [...] They have corrected it through the efforts of the Fathers, mixing it with Christian demonstrations and sentiments and pity toward the dead, and, upon hearing the tolling of the bell, they come together, ordinarily more than 1,000 souls, and they accompany the dead until giving them burial $[. . .]^{31}$

The second issue is that the Jesuit sources probably declined to mention those indigenous practices that would have compromised the general image that they wanted to convey to the European world about the missions of Paraguay. If indeed it is true that those elements tied to the former reko or "way of being" of the Guaraní were eradicated, many aspects of this long process of resignification still remain confused.

Reports about religious practice in the Guaraní missions, especially those dating from the eighteenth century (like the writings of Peramás), tend to draw a stark contrast with the ways of life and former religion of the groups under missionary control. Only a few accounts of the old rituals can be found in the early writings of the Jesuits, and these are generally based on secondary information. For example, consider the letter that the Jesuit Barzana wrote ten years before the creation of the Jesuit Province of Paraguay, in which he supplied information on the indigenous Guaraní and Chaqueño. In this letter, Barzana writes, "[the Guaraní] have so many dances based on their religion and perform them so stubbornly that some die during them." ${ }^{32}$

These sources do not bring anything new to ethno-historic or musicological research. Nonetheless, it is interesting to extract from them the fact that the Jesuit perceived indigenous practices as a permanent threat to missionary activities insofar as they served as the basis of resistance conducted by the indigenous religious leaders. Barzana writes,

And this propensity of theirs to obey religious titles has caused not only many infidel Indians to pretend amongst themselves to be children of God and teachers, but also [Christian] Indians, raised amongst Spaniards, to run away and join those still at war, and some calling themselves Popes, others calling themselves Jesus Christ, have clumsily set up monasteries with nuns quipus abutuntur; and, to this day, those who serve and those who do not serve have sown a thousand omens and superstitions and rites [learned] from these teachers, whose principle

30 Lluís Palomera Serreinat, Un ritual bilingüe en las reducciones del Paraguay: el manual de Loreto (1721), Dissertatio ad Doctoratum Sacrae Liturgiae assequendum in Pontificio Instituto Liturgico, n. 283 (Romae: Thesis ad Lauream, 2001).

31 In Cartas Anuas de la Provincia fesuítica del Paraguay, 1632 a 1634, introducción del Académico de Número Dr. Ernesto J. A. Maeder, edición en homenaje al Quinto Centenario del Descubrimiento de América. (Buenos Aires: Academia Nacional de la Historia, 1990). Herafter CA (1632-34).

32 Guillermo Furlong, Alonso de Barzana, S.F. y su carta a Fuan Sebastián (1594). (Buenos Aires: Ediciones Theoria, 1968$), 93$. The value of this letter is perhaps exaggerated in Bartomeu Meliá, El guarani conquistado y reducido. Ensayos de etnohistoria (Asunción: Centro de Estudios Antropológicos, Universidad Católica Ntra. Señora de Asunción 1986). 
doctrine is that one must dance, day and night, and as a result [Indians] die of hunger, having forgotten their crops. ${ }^{33}$

Dance and song were conceived as performances that had irrevocable consequences: they were the means by which "sorcerers" reached a state of perfection known as agujye, in which the physical world dropped away. ${ }^{34}$ Much later the Jesuit Pedro Lozano would highlight similar practices while documenting the famous rebellion against the Spanish led by Oberá. He writes:

Oberá took his time on the way to the Paraná, enjoying the torpid delights. He maintained a crowd of concubines with which he occupied himself in abominable dances and songs composed for his own praise, and he persuaded all the others that if they should wish to remain in his favor, then they should do the same day and night. They obeyed him promptly, because the license to do vice is the most powerful aid to garner obedience among barbarians. All the time they were not heading to infest Asuncion they spent singing praises to their adored Oberá, extolling his power, majesty, and other attributes he credited himself with in his diabolical pride. The danger in the province grew moment by moment because of the entourage and potency of Oberá, attracting Indians from distant parts to worship this fabulous deity.”35

The early descriptions do not afford us greater details, which makes it practically impossible to reconstruct the characteristics of the older rituals. Also, it should be kept in mind that the groups that came under missionary control during the seventeenth century were diverse and had different cultural traditions. This makes it difficult to speak of homogeneous socio-cultural practices when the Jesuit missions first began.

The only thing we can say with certainty is that the tradition of the festival was fundamental among the groups under direct missionary control. This was documented in the seventeenth century in the linguistic work of Ruiz de Montoya, who devotes many definitions to the Guaraní term "festival." 36 These definitions were clearly appropriated and re-signified in the missions for the purposes of evangelization. Ruiz de Montoya translates the term "fiesta" (festival) as Areté. This term, a compound of the particles Ara, "time (or day)," and Eté, "true," appears at the same time in the Tesoro de la Lengua Guaraní ("Thesaurus of the Guaraní Language”) covering a wide range of uses and contexts. It refers to Saint days, to the Easter celebration of the resurrection (Areté guaçù), to the "Easter of the Nativity" (Tupa mitangi areté guaçu), to the feasts in their totality, to feasts which fall on Thursdays, to the actions of observation, preparation, and purification for those feasts, the work done on feast days, the celebration of the mass, and the act of going to church, among others. ${ }^{37}$ The term

33 Ibid., 93.

34 Hélène Clastres, La tierra sin mal (Buenos Aires: Ediciones del sol, 1989).

35 Pedro Lozano, Historia de la Conquista del Paraguay, Río de la Plata y Tucumán, vol III (Buenos Aires: Casa Editora "Imprenta popular," 213-214.

36 "Festival, dinner party. Pepi. Carú guazú. To make a festival, feast. Aipe pirv. Acarú guazú mona. To prepare a festival, feast. Ane mbocacoí pepi rehé. Festival of watching. Areté. Ára marândecó habey. Mara tequâ beyma. Festival of relaxing. Toriba. To make a party. Atarimona. Atoriberecó. Festival of games. Nembocarầ. Adjacent festivals. Areté yoapi api. Oyoeché bé hebe arete. Oyoehé eheí" (Ruiz de Montoya, 4).

37 "Areté abaupé guâra co nanga Domingo ñabo . l. areté tapiá, the feasts of the Indians are these, all Sundays of the year. Areté guacú mitang áhagûera arypy, the first day of Easter of Nativity. Mburubichabeté areteguacú, Easter of Kings. L. N. Y. Recobé yebyhagûera arypy, First day of Easter of Resurrection. Mitangy yquyti haguêra, the day of the Circumcision. 
festival also appears to be associated with the Guaraní concept of pepy-get-together or feast-the intimate linkage being through similar practices and an emphasis on group cooperation. ${ }^{38}$

The use of these terms would become common with the consolidation of Jesuit proselytizing activities in the area. In the eighteenth century, for example, we find a priest like Jaime Oliver for whom it is natural to use the term aretéguaçú to refer to the "fiesta magna" of the Christian calendar among the Guaraní. ${ }^{39}$ In short, such a redefinition makes evident the centrality of the concept of the festival in the Guaraní worldview and daily practices. We should continue to investigate the concrete meanings of terms such as this.

Now it is equally evident that the Jesuits were clearly conscious of the limitations of appropriating certain former practices. By their association with the figures of religious leaders, some practices that persisted could put at risk the stability of mission life and the imposition of Christian religious ideas. Although we cannot confirm that an element of drunkenness was ubiquitous in the old indigenous rituals, and are similarly limited with respect to the role of body painting, nudity, or certain hairstyles, it was inevitable that Jesuit officials would eradicate them, not only because they were seen as symbols of barbarity and contrary to civic life, but, more importantly, because they were signs of native religious identity. According to a Carta Anua ("Annual Letter") by Jesuit Diego de Torres, the Guaraní of Guayrà used the skulls of their enemies as cups for chicha, a drink made from corn that they frequently imbibed to make themselves drunk at their banquets. ${ }^{40}$ Peramás also refers to the custom of "tinting the face" and identifies it with barbarian women. ${ }^{41}$ Of practices like cannibalism, which was an anathema within the missionary controlled regions, we have no generalized evidence, but we suspect that they were found diffused throughout several areas where missionary activity took place.

Iesu Christo ybápe yyeupí haguêra, the Ascension. Tupa Sipritu Santo aretéguacú arypy, the first day of Easter of Holy Spirit. Tupacy áhagúera, the Birth of our Lady. S. Gabriel Tupacy yhupaguêra, the incarnation of the Lord. Tupacy ymembirá rirè, Tupa ópe yhóhagûera, the Purification. Tupacy ybápe yhó hagûera, the Assumption. S. Pedro hae S. Pablo aretê, the feast of the Apostles S. Peter and S. Paul. Tupa reroataguacu, day of the Corpus" (Ruiz de Montoya, 67-67 v.).

38 Wilde (2004). Convites (feasts) are held for those who help construct a house, for those who contract in marriage and celebrate the Eucharist ("hazemos Dios combite con su carne"-we invite God with his flesh). Ruiz de Montoya writes: "Pepy. Combite, og pepy, feast that they hold for those who help make a house. Pepyguacù, a great feast. Aipepyru, to hold a feast. Ambo pepy chemendára, to hold a feast upon a marriage. Chepepyra reábo aycó, to go about looking for supplies for a feast. Tupa oñembo pepy ñandébe, guoó hoù vcábo, we invite God with his flesh. Pepy oñerv, hizose combite. Pepy ybápe guâra noñeruíri apyreyma, without end shall persevere the celestial feast" (Ruiz de Montoya, 268 v.).

39 "In the areteguaçu, which they call the fiesta magna [great festival] of the Village there are, after the Church service in the morning, public dances in the plaza: for that day they invite various peoples [...] belonging to the neighboring Villages; and they bring the best of their Music to celebrate the feast, and to enliven the celebrations in the plaza. Many needed things are given out to the people that day: like knives, daggers, scissors, medals, many cuts of clothing, glass beads, pendants, and rings for the Women. In the afternoon they have their games of rings or canes on horseback, their dances and farces in the plaza: and in the evening on that day they often put on an honest opera performed by boys, but with such delicacy that it could show in Europe." (Oliver, cited in Estela Auletta, "El P. Jaime Oliver S.J. y su "Breve noticia de la numerosa y florida cristiandad guaraní," in Missoes Guarani. Impacto na sociedade contemporanea, ed. Regina Gadelha, 144 [Sao Paulo. Educ-Editora da PUC-SP, 1999]).

40 Cardiel writes in his Carta y Relación [Letter and Relation] that most of the enemies they captured they ate and afterwards cleaned out the skull, which they used as a cup for chicha or corn beer in their celebrations (Aníbal Ruiz Moreno, La lucha antialcohólica de los jesuitas en la época colonial. [Buenos Aires: Cátedra de Historia de la Medicina, Universidad de Buenos Aires, 1939], 31 - 33).

41 Peramás, 146. 


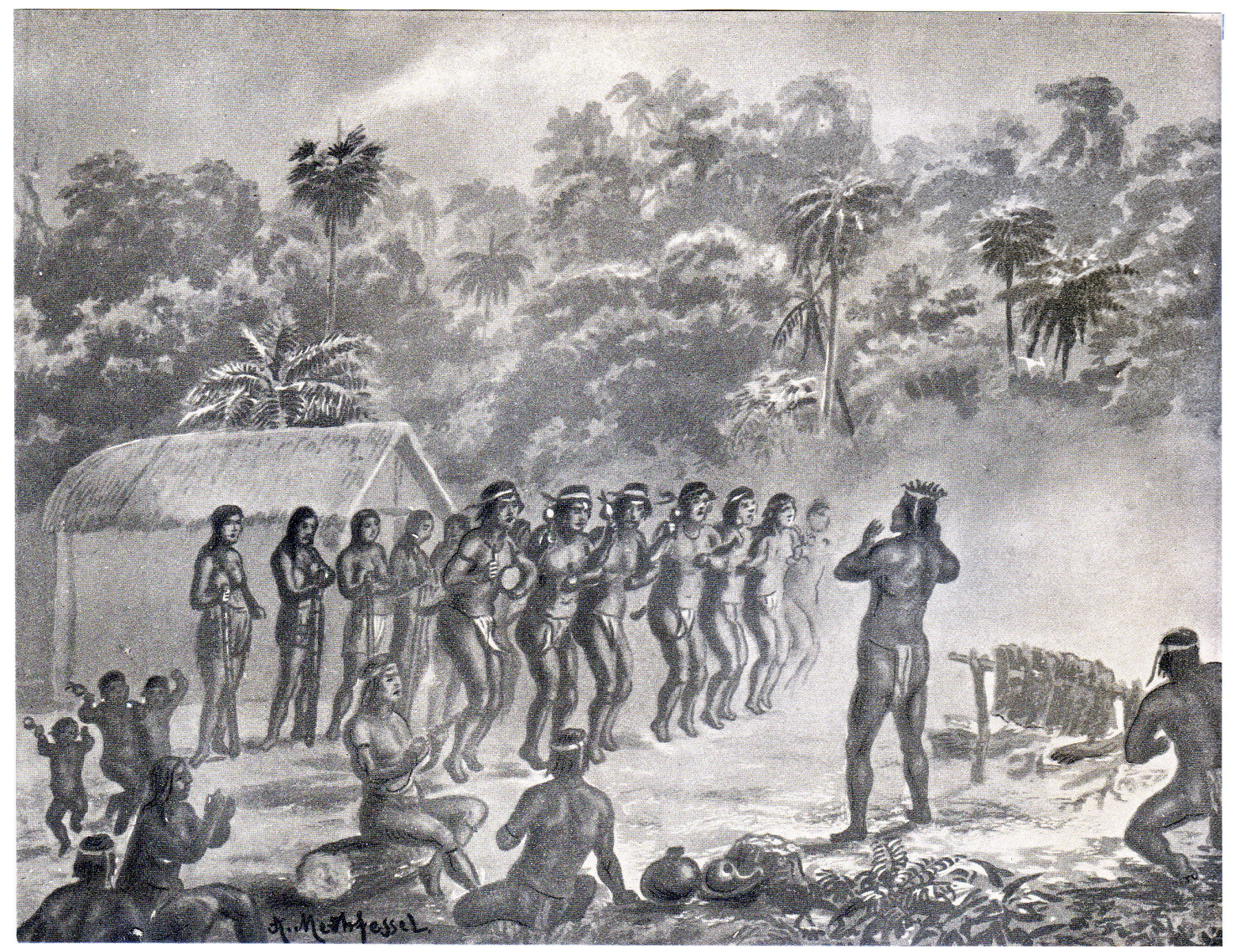

Figure 10. Guarani Celebration (end of $19^{\text {th }}$ Century) by Adolf Methfessel for the book of Juan Bautista Ambrosetti 1894 "Los indios Cainguá del Alto Paraná (Misiones)". Boletín del Instituto Geográfico Argentino 15:661-744. Buenos Aires. Published by Vignati: Anales del Museo de La Plata.

All of those practices that could be identified with the old ways of indigenous life and particularly those associated with celebrations were zealously persecuted. For example, the practice of ritual drunkenness was gradually replaced by taking infusions of yerba mate (Paraguayan tea) or, in the worst of cases, measuring out chicha and guarapo of low alcohol content during festivals and gettogethers. The Jesuit Muriel explains that after mass and prayers, a ration of yerba was doled out to each Indian, which he or she generally consumed during working periods. The drink, he indicates, was capable of invigorating them without making them drunk. ${ }^{42}$ Peramás later praised the drink in the following manner:

During the whole time that I lived among them, I never saw, in any city, a single drunk. They contented themselves with their own drink of Paraguay herb [yerba mate], which they highly esteem; a drink that can be taken twenty times an hour or in half that without the least damage. I refer to what I myself have seen and experienced. ${ }^{43}$ 
We also know that, at least in the beginning, the use of musical instruments with religious significance, such as maracas and tacuaras, was condemned. It is revealing to consider several surviving testimonies of indigenous people who witnessed the martyrdom of the Jesuits Roque González de Santa Cruz, Alonso Rodríguez, and Juan del Castillo, which occurred in the villages of the Tape region. For example, Cristóbal Quirendí affirms that an old sorcerer named Guaraibí ordered the kidnapping and murder of Juan del Castillo, saying to the Indians: "Let us kill this priest: let us have only our chief Nezú, let there be heard in our lands the sounds of our gourds and taucaras." ${ }^{44}$ Once the Jesuit was taken prisoner, the Indians entered the priest's house and the church as a group, destroying images and the altar and gathering up the ornaments to take them to the head of the rebellion, the sorcerer Ñezú, who ordered them burned. Another witness, the chief Guirayú, from the village of Candelaria, corroborates this by indicating that the aforementioned sorcerer Guaraibí exhorted the Indians, telling them that there should only be heard in their land the sound of gourds and that "women Indians should hear the sound of our tacuaras." And he added: "These Fathers are the reason we hide our gourds and tacuaras." 45

We reach the point where an "ethnographic analogy" is opportune. As Irma Ruiz shows in successive works, among the current mbyá guaraní groups in the province of Misiones, in the precinct called opy, there exist two sonorous instruments that are indispensable to ritual undertakings due to their sacred character. One of them, used by men, is the mbaraká, shakers made from a gourd and later replaced by the five-string guitar. The other, the takuapú, is a rhythm stick made from the takuara cane and used ritually only by women. ${ }^{46}$ The link between these sound instruments and the religious and socio-cultural identity of the mbyá and other Guarani subgroups like the Chiripa/Nandeva and the Kaoiwa/Pai is indisputable. ${ }^{47}$ It is difficult to confirm the historic link between these contemporary groups-which escaped subjugation-and the Guaraní of the seventeenth century in Tape. But it is evident that both pairs of instruments, the takuapú and the mbaraká on the one hand and the tacuaras and gourds on the other, have similar roles in the construction of collective Guaraní identity.

44 José María Blanco, Historia documentada de la vida y gloriosa muerte de los padres Roque Goinzalez de Santa Cruz, Alonso Rodríguez y Juan del Castillo de la Compañia de Jesús, mártires del Caaró e Yjuhí (Buenos Aires. Sebastián de Amorrortu. 1929), 447-448.

45 Ibid., 452.

46 Ruiz gives us the following description: "Originally, [mbaraká] designated an idiophone activated by an indirect strike or by shaking, made from a gourd (fruit of the Legendaria siceraria) pierced by a stick, whose lower part served as a handle, and that carried inside it small fruits. Today it designates a guitar with five strings, since the former has lost relevance. To distinguish them, the shaker is called mbaraká mirí, an adjective that means small, in comparison with the guitar [...] Concerning the takuapú, the view is different. In addition to still being in use, the sources are in consensus. It is a directly struck idiophone, tubular in its shape, and generally called bastón or rhythm tube. It made from a piece of takuara (Guadua angustifolia) or takuarusú (Guadua Trinii), whose length is determined by the distance between three nodes (70 to $90 \mathrm{~cm}$ ). The lowest node is the only one that is kept: the intermediate one is perforated and the upper one is removed so that the piece can be made hollow. The diameter varies between 4,5, and $7 \mathrm{~cm}$. It produces a sound upon striking it on the ground" (Irma Ruiz, "La ceremonia Nemongaraí de los Mbiá de la Provincia de Misiones," Temas de Etnomusicología 1 [1984]: 71). For the idea of "ethnographic analogy" see such classic works as those of Nimuendajú, Cadogan, Schaden and Müller. For a musical example, please see the link at the conclusion of this article.

47 Graciela Chamorro, Kurusu ñe'ëngatu. Palabras que la historia no podría olvidar (Asunción: Centro de Estudios Antropológicos, Universidad Católica, 1995); Miguel Alberto Bartolomé, Chamanismo y religión entre los Ava-Katu-Ete (Asunción: Centro de Estudios Antropológicos, Universidad Católica,1991). 


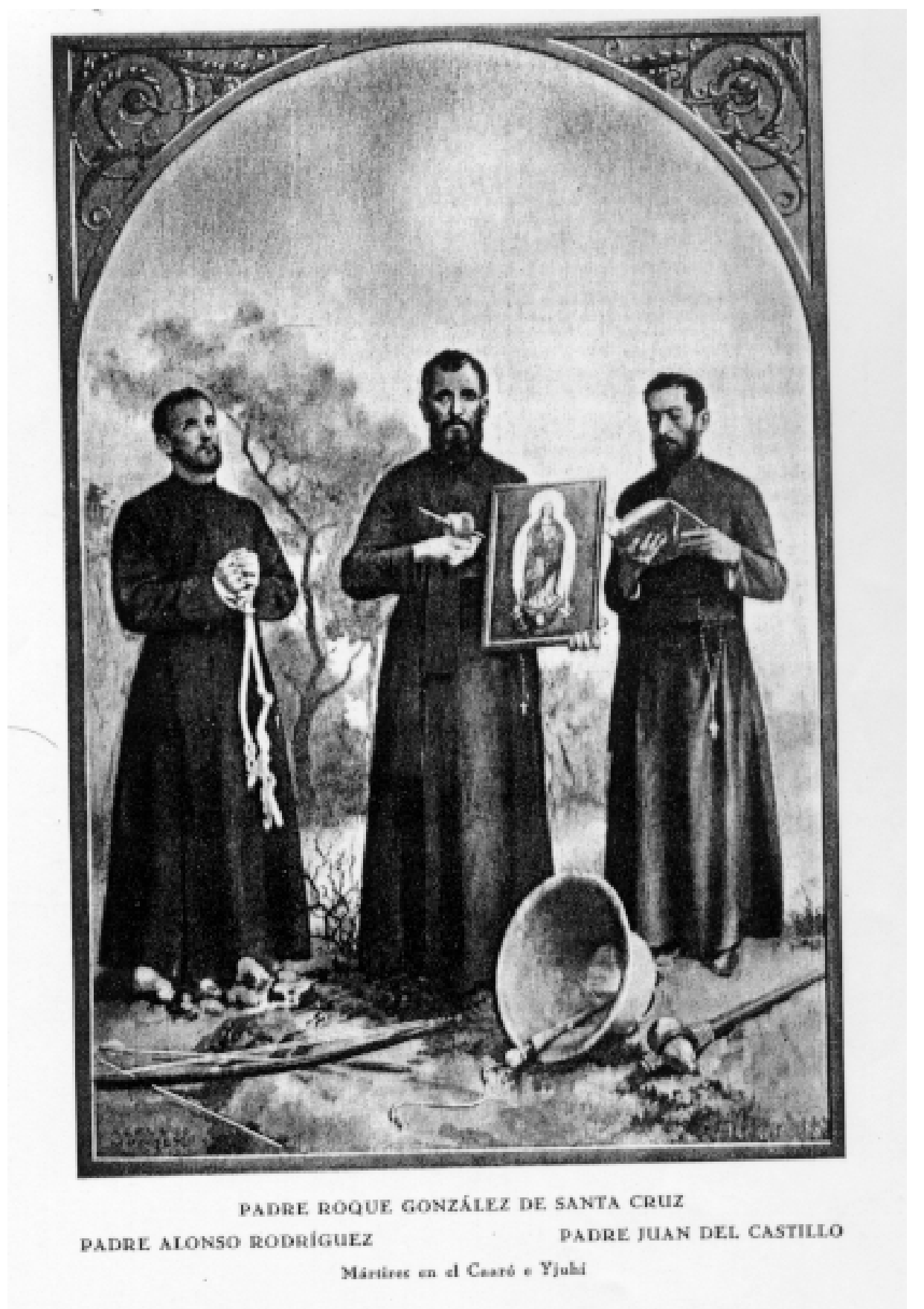

Figure 11. Jesuit Martyrs of Caaró, Roque Gonzalez de Santa Cruz, Alonso Rodriguez and Juan del Castillo (picture from: Blanco 1929) 


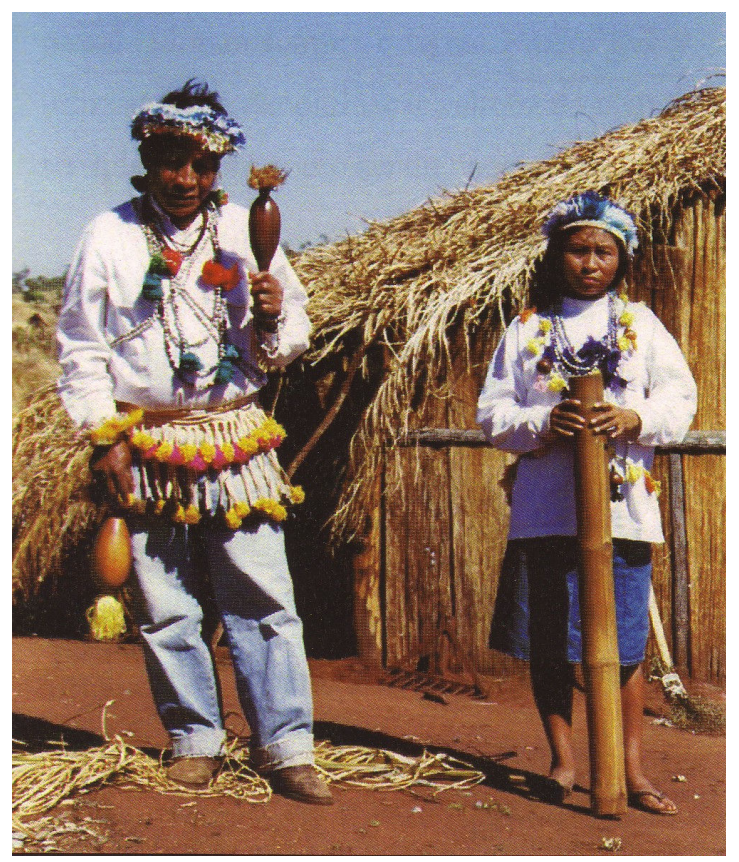

Figure 12. Atanás Teixera and his wife Roberta with maraca y takuá, Nande ru Marangatú, Brazil, 2000. Picture from: Mura, Fabio: A Procura do "Bom viver". Territorio, tradiçao de conhecimento e ecologia doméstica entre os Kaiowa. Doctoral dissertation, Graduate Program of Social Anhtropology, Museo Nacional, Federal University of Rio de Janeiro.

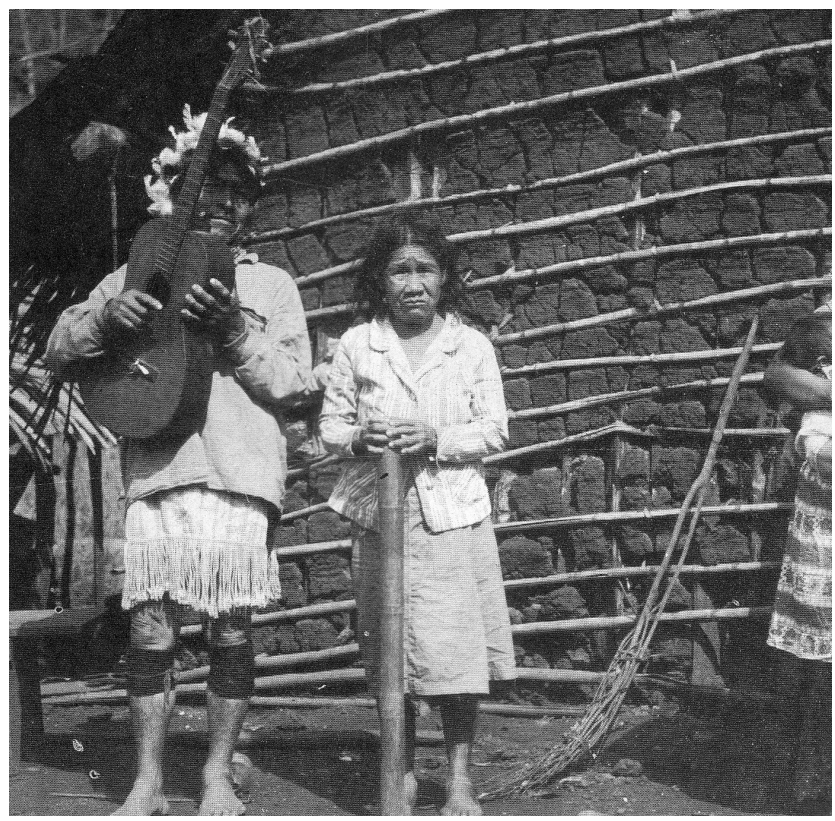

Figure 13. Pa'I Antonio Matinez and his wife Paula Mendoza with mbya guitar (mbaraka) and takuapú (picture from: Ruiz 1984) 
To sum up, the events of Nezú's rebellion allow us to infer that the indigenous populations were conscious that rejecting the Christian subjectivity being imposed upon them entailed destroying the sonic and visual symbols that served as its vehicle. In doing so, they could restore the former sound and rituals that constituted symbols of their own subjectivity. ${ }^{48}$ The Jesuit sources refer frequently to this kind of ritual combat. At times, the central goal of the indigenous rebels was to appropriate the images and sounds employed by the Jesuits as instruments of domination. These would be reused or destroyed, but in either case their hegemonic use was undermined. The Jesuits related such rebellions with the intervention of malign beings. ${ }^{49}$

It is worth highlighting the importance of these "spaces of subverted order" that appear and reappear through sonic traces in several moments in the history of the missions of Paraguay. In order to understand the political uses of sound by indigenous peoples, we need to consider other significant episodes like the rise of Nezú and his followers. An early Carta Anua relates that in the zone called Ibiá, on the missionary front of Uruguay, a group of leaders spread the idea that natural sounds were the voices of monsters hidden in the interiors of mountains-monsters that would attack those Indians who accepted Christianity. ${ }^{50}$

Sources from the Guayrá region describe a "sorcerer" who came from Brazil along with his wife and a slave. In the village of Loreto, he presented himself in public

[...] covered in a cape of feathers sounding castanets made of goat skulls and jumping crazily; he claimed that he was the true lord of death, of women and of grains; that all was subject to his will; that with his breath he could annihilate the world and return to create it, that he was a god in three persons, that through his ritual he had given being to his slave and from the two of them was produced the girl they brought with them and with whom they united carnally. ${ }^{51}$

If we move forward in time to the eighteenth century, we discover another significant episode. During the conflict known as "the guaranitic war," which came about in the decade of 1750, the indigenous populations of seven Guaraní villages arose against the Spanish and Portuguese rulers, who had required the villagers to relocate to new lands after signing a boundary treaty. Around 1753, the Jesuit of one of the villages, who tried in vain to mitigate the conflict, wrote to the authorities of the Society of Jesus. He explained that everything in the village was agitated and that day and night the indigenous residents deafened him with the beating of boxes. They stalked him and yelled incessantly like infidels, accusing him of wanting to turn them over to the Portuguese. ${ }^{52}$

48 In the village of Jesús María, “[t] he rebels of the Caro, after treacherously murdering the illuminated martyr Father Roque Gonzáles, hid with great diligence the bell he [Father Roque] had been ringing in order to call them to the catechsim [...]" (CA [1632-34], 182).

49 The Jesuit Jarque writes, "A demon declared that the bell which announced mass, catechism, and sermons had to be pulled down and, God permitting it, he broke it. P. Antonio had put it in a little tower made of wood. It was rung throughout the day they placed it there, and the following, at the first stroke of the call to mass, it was recognized that it was broken [...]" (Jarque cited in Bernardo Illari and Ricardo Zavadiker, "Repertoiro de documentos sobre música de las reducciones Jesuíticas de la Provincia del Paraguay," [Chicago-Córdoba, 1993]).

50 Itala Irene Basile Becker, "Lideranças indígenas no começo das reducoes jesuiticas da provincia do Paraguai," Pesquisas Antropologicas 47 (Instituto Anchietano de Pesquisas. Sao Leopoldo,1992): 49.

51 Cited in Ibid., 49.

52 Furlong, 662. 
In this episode, as in the previous ones, sound is something more than an indication of political resistance. Rather it establishes a space of indigenous subjectivity that escapes control, evoking, in some cases, an older Guaraní "way of being"-or better yet, "sound of being"-that codifies antecedents and calls for a collective unity based on indigenous religion against the new Christian order. A structural similarity links these episodes with the first stages of resistance to conversion, marked by song and dance..$^{53}$

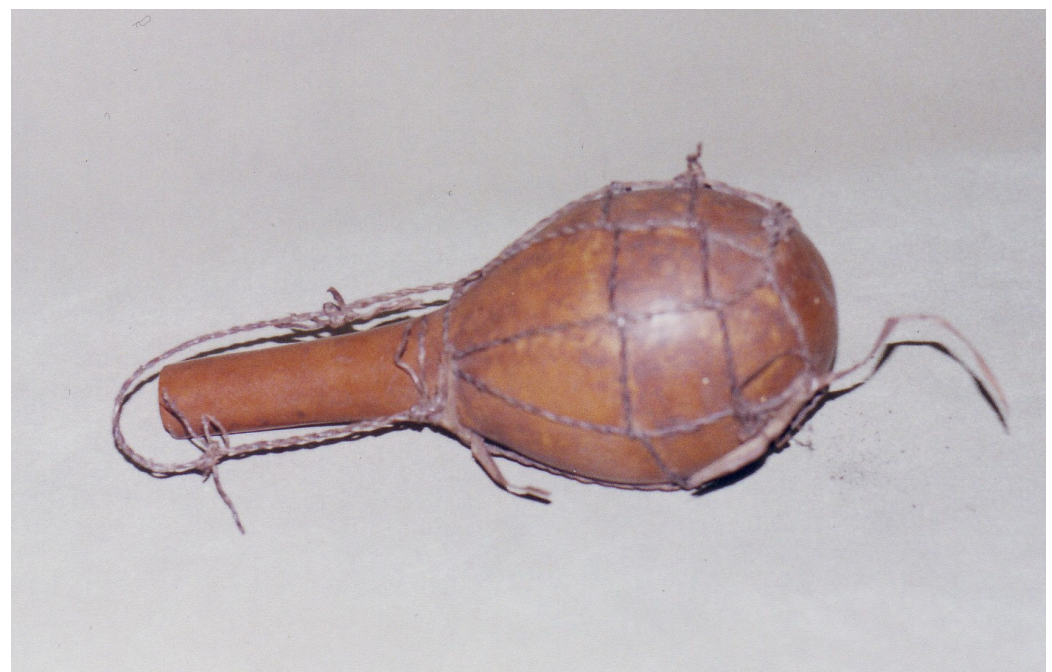

Figure 14. Guarani maraca from the colection of "Juan Bautista Ambrosetti" Ethnographic Museum, School of Philosophy and Letters, Buenos Aires University (author's photo).

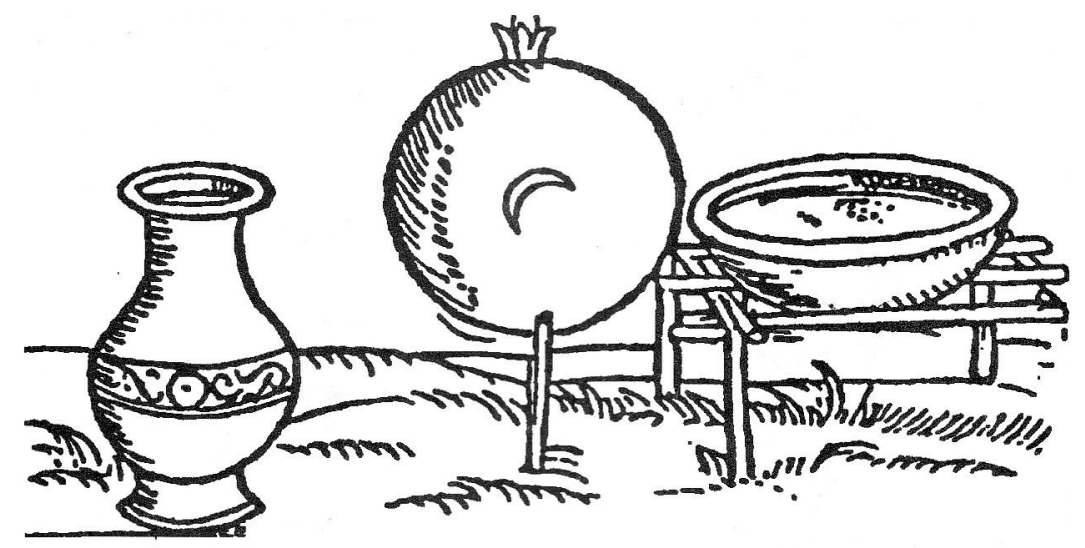

Fonte: Staden, 1974, p. 173.

Figure 15. Tupi maraca, according to Hans Staden (1557). Picture from: Staden, Hans 1974 Duas viagens ao Brasil. Belo Horizonte: Ed. Itatiaia/ Ed. da Universidade de São Paulo.

53 For a review of the successive indigenous uprisings against the imposition of Jesuit order see the exhaustive work of Daisy Rípodas Ardanaz, “Movimientos shamánicos de liberación entre los guaraníes (1545-1660)," Apartado de Teología XXIV, no. 50 (1987): 245-275. 
In effect, these ancestral practices reveal to us a fundamental aspect of indigenous culture that we may call an "erotic dimension of sound"; this is inscribed at the level of bodily pleasures that, by being intrinsically linked with a space of contestation of the established order, are generally controlled and repressed, or in the best of cases laboriously resignified. Such a dimension is linked with a singular subjectivity that unfolds in the daily and ritual environment and creates connections with its ancestors. It is probably within this frame that an interpretation of the persistence of the song-form known as guahú should be mentioned. If indeed the missionaries did not assign it much importance, its performance was strictly controlled in the missions and considered dangerous to good manners. ${ }^{54}$ As Escandón relates, this type of lamentation, which was practiced by women, continued to be used in the Jesuit era for the celebration of indigenous funerals. ${ }^{55}$

To conclude, perhaps it is useful to return to the ideological construction that the Jesuits bequeathed us. These men had been charged with constructing an opposition between the rituals of the Christian sphere, to which the missions of Paraguay were to aspire, and the rituals proper to the older indigenous "way of being," described in a vague and confused manner in their documents. In this simplistic dichotomy, the old rituals, manifest in the old dances and songs, were expressions of a "barbarous" way of life, prolixity, excess, disorder, and the impulsive release of the passions. By contrast Christian rituals, embodied in the sounds of European music, symbols, and images, were expressions of civil life, moderation, rationality and order. The dichotomy was also expressed in terms of a disciplinary relationship, whereby the Christian was meant to domesticate the "savage" by means of vigilance, public humiliation, and corporal punishment.

Now we must ask, is it possible to go beyond this dichotomy, making use of the Jesuit sources available?

\section{Beyond Domination and Resistance: Hybrid Sonic Spaces}

It is useful to point out that the analytical distinction between hegemonic and counter-hegemonic uses of sound presented here is probably only valid for the first, formative stage of the missions. As may already be noted from the documents presented, the dual scheme turns out to be too simplistic to tackle the ritual and sonic phenomenon in periods subsequent to the Paraguayan missions. Though we know that the Jesuit model ended up being successfully imposed, the result was not a pristine reflection of the model, but rather it generated a series of hybrid spaces in which certain elements of the indigenous vision were re-signified or kept covered in silence. In addition to the traditional group of primary sources such as the cartas anuas and reports, a broader and more diffuse corpus of Jesuit documentation needs to be considered. Letters to Father General, memorials, rule books etc.-all of

54 Becker, 43-44.

55 " [...] Their burials and those of all other adults are done in this manner. [...] And at the time of burial the altar boys go for the deceased with the Father, dressed in a black rain cape, and the musicians and, from there, the burial party is ordered up to the church, in which the eulogy is sung, etc. [...] While the body is put in the sepulcher, the cries of the mother, wife, or relatives start with a kind of lugubrious singing that is so dissonant that it is impossible to explain. This song or wail, in their language guahú, or lamentation, is sung by the women. In it they sing, cry, or rave about the deceased, saying not only what he was, but what was hoped he would have been had he not died" (Juan Escandon, Carta al Padre Andrés Marcos Burriel, in Guillermo Furlong, Fuan Escandón y su carta a Burriel (1760) [Buenos Aires. Ediciones Teoría, 1965], 101-102). 
these would allow us to gain a more precise image of this universe of socio-cultural and political practices.

Between the poles of domination and resistance surely we can find a broad repertoire with intermediating nuances that express subtle modalities of indigenous agency. We know practically nothing of the limits of the sonic universe of the missions, the eventual acceptance of native musical instruments, and the performance practices that developed for the European instruments adopted by the indigenous people. For example, it is still necessary to explain the wide-scale incorporation of instruments like the maracas (evidenced in the series of angel musicians on the frieze from the village of Trinidad) into a sonic context mainly defined by the presence of European instruments, or the enduring staying power of the guahú, along with other similar continuities that persist in indigenous groups today. We must also explain why certain European instruments had greater acceptance among certain indigenous villages. How did certain timbres contribute to defining collective identity and reflect social or aesthetic preferences among the indigenous population? How did the knowledge of music (interpretation, composition, the job of copyist or of chapel master) influence the construction of political prestige? These questions, posed here in the last section, have a preliminary character. They are oriented towards the search for new elements that can be incorporated into the reconstruction of native conceptualizations and into the drawing of a sonic missionary map.

In the previous pages I have tried to delineate a model of analysis in which clues are extracted concerning the linkage between the sonic universe and daily and ritual life in the missions. I began with the premise that when we speak of sound we always speak of something more, something that has to do with how subjects conceive of themselves, and with the society in which they live, putting into play an "erotic dimension of sound." This dimension is situated on the plane of pleasure and desire, emotions that, although they can be subjugated to an order and the object of control, can also "subvert," in ways open or subtle, escaping even conceptualization, like remnants or remainders of a reality that is irreducible to normal language. 


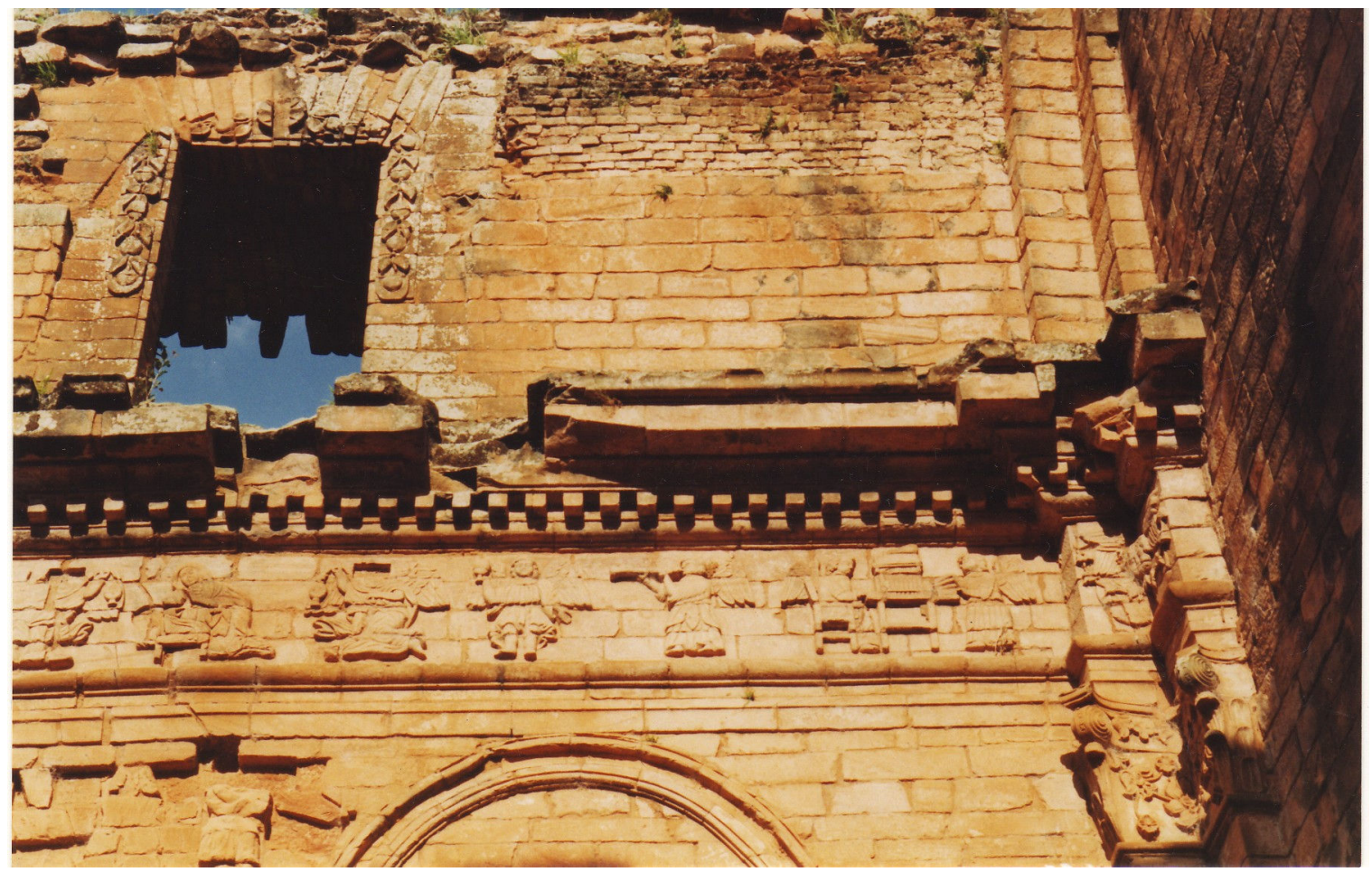

Figure 16. Frieze of Angel musicians, village of Santísima Trinidad, Paraguay (author's photo)

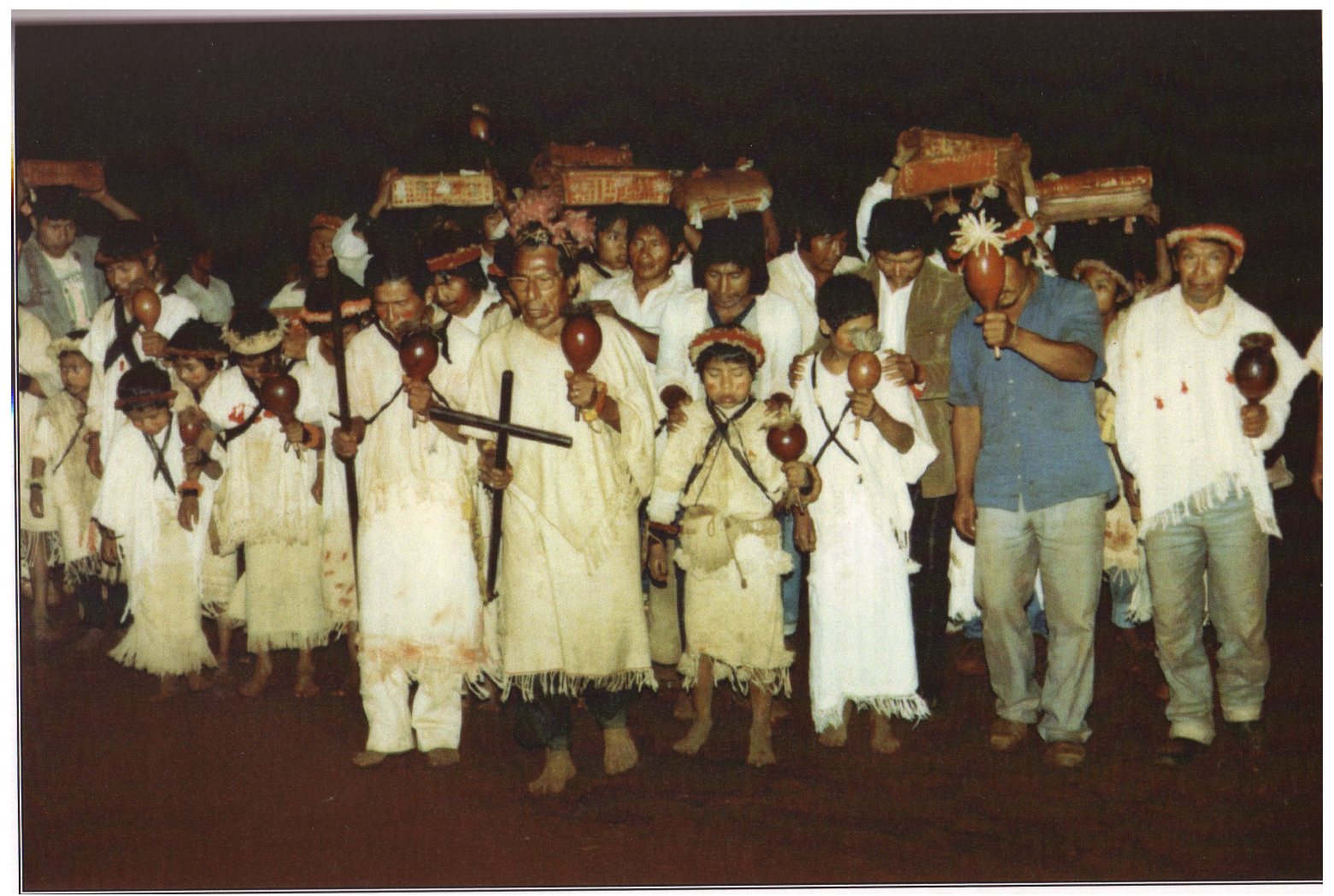

Figure 17. Celebration among the kaiowá of Mato Grosso do Sul, Brazil . Picture from: Mura, Fabio: A Procura do "Bom viver". Territorio, tradiçao de conhecimento e ecologia doméstica entre os Kaiowa. Doctoral dissertation, Graduate Program of Social Anhtropology, Museo Nacional, Federal University of Rio de Janeiro. 


\section{Musical Examples}

\section{Musical Example 1}

Accessible at: http://dx.doi.org/10.3998/mp.9460447.0001.204

Description: Kyrie from Johann Caspar Kerll's Missa in fletu Solatium obsidionis Viennensis.

Performer: Johan Rosenmüller Ensemble, Arno Paduch (conductor)

Label: Christophorus/AMG-Classical, 2000.

\section{Musical Example 2}

Accessible at: http://dx.doi.org/10.3998/mp.9460447.0001.204

Description: "Guarani Kaiova Brazil"

From: Deise Lucy Oliveira Montardo’s Através do Mbaraka: Música e xamanismo Guarani (2002)

Tese de Doutorado. Faculdade de Filosofia, Letras e Ciéncias. Universidad de Sao Paulo. Track 8: Odúlia 1- Noite 06 - Al Amambai/MS.

\section{Musical Example 3}

Accessible at: http://dx.doi.org/10.3998/mp.9460447.0001.204

Description: "Guarani Mbya Argentina 1973"

From: Instrumentos Musicales Etnográficos y Folklóricos de la Argentina. Documentos producidos durante investigaciones de campo. Instituto Nacional de Musicología "Carlos Vega." Edited by Yolanda Velo.

Track 1: Performers: Paula Mendoza, Clemencia Escobar, Antonio Marinez y Mario Silva. Misiones, Colnia Gob. Lanusse, Argentina, 1973 (Colector: Irma Ruiz).

\section{Bibliography and Sources}

ALVAREZ KERN, Arno 1982 Missoes, uma utopia politica. Porto Alegre. Rio Gande do Sul.

ANDRIOTTI, Décio 1999 A discografia do padre Sepp: na busca de probabilidades. Missoes Guarani. Impacto na sociedade contemporanea. Gadelha, Regina (ed.). Sao Paulo. Educ-Editora da PUC-SP.

AULETTA, Estela 1999 El P. Jaime Oliver S.J. y su "Breve noticia de la numerosa y florida cristiandad guaraní”. Missoes Guarani. Impacto na sociedade contemporanea. Gadelha, Regina (ed.). Sao Paulo. Educ-Editora da PUC-SP.

BARTOLOMÉ, Miguel Alberto 1991 Chamanismo y religión entre los Ava-Katu-Ete. Asunción: Centro de Estudios Antropológicos, Universidad Católica.

BECKER, Itala Irene Basile 1992 Lideranças indígenas no começo das reducoes jesuiticas da provincia do Paraguai. Pesquisas Antropologicas 47. Instituto Anchietano de Pesquisas. Sao Leopoldo.

BLANCO, José María 1929 Historia documentada de la vida y gloriosa muerte de los padres Roque Goinzalez de Santa Cruz, Alonso Rodríguez y Juan del Castillo de la Compañía de Jesús, mártires del Caaró e Yjuhí. Buenos Aires. Sebastián de Amorrortu.

CA [1632-34] 1990 Cartas Anuas de la Provincia Jesuítica del Paraguay, 1632 a 1634. Introducción del Académico de Número Dr. Ernesto J. A. Maeder. Edición en homenaje al Quinto Centenario del Descubrimiento de Améric. Buenos Aires. Academia Nacional de la Historia.

CARDIEL, José [1758] 1900 Misiones del Paraguay - Declaración de la verdad. Buenos Aires. Imprenta de Juan A. Alcina.

CHAMORRO, Graciela 1995 Kurusu ñe éngatu. Palabras que la historia no podría olvidar. Asunción: Centro de Estudios Antropológicos. Universidad Católica. 
CLASTRES, Hélène 1989 La tierra sin mal. Buenos. Aires. Ediciones del sol.

CRO, Stelio 1992 Empirical and Practical Utopia in Paraguay. Dieciocho 15 (1-2): 171-184.

DOBLAS, Gonzalo de [1785] 1836-1837 Memoria histórica, Geográfica, política y económica sobre la Provincia de Misiones de indios guaraníes. En: Colección de obras y documentos relativos a la historia antigua y moderna de las Provincias del Río de la Plata. DE ANGELIS, Pedro. Buenos Aires. Imprenta del Estado.

DUMONT, Louis 1991 [1983] Essais sur l'individualisme. Une perspective anthropologique sur l'ideologie moderne. Paris. Éditions du Seuil.

ESCANDÓN, Juan [1760] 1965 Carta al Padre Andrés Marcos Burriel. En: FURLONG, Guillermo 1965 Juan Escandón y su carta a Burriel (1760). Buenos Aires. Ediciones Theoria.

FURLONG, Guillerrno 1962 Misiones y sus pueblos guaraníes. Buenos Aires. Imprenta Balmes.

FURLONG, Guillermo 1968 Alonso de Barzana, S.J. y su carta a Juan Sebastián (1594). Buenos Aires. Ediciones Theoria.

GEERTZ, Clifford 1994 Conocimiento Local. Barcelona. Gedisa.

HESPANHA, Antonio Manuel 1994-1995 "Las categorías del politico y de lo juridico en la época moderna”. Ius fugit 3-4: 63-100. [versión manuscrita utilizada]

ILLARI, Bernardo 1998 "Un Laudate Pueri Como Antiobra (Acerca De La Invención De La Música Jesuítica De Chiquitos)." Música Barroca Del Chiquitos Jesuítico. Trabajos Leídos En El Encuentro De Musicólogos. (Santa Cruz de la Sierra, ).

ILLARI, Bernardo 2001 Polychoral Cultura: Cathedral Music in La Plata (Bolivia) 1680-1730. Ph. D. Dissertation. Department of Music. The University of Chicago.

ILLARI, Bernardo 2004 "El Sonido De La Misión: Práctica de Ejecución e Identidad en las reducciones de la Provincia Del Paraguay." Música colonial Iberoamericana: interpretaciones en torno a la práctica de ejecución y ejecución de la práctica. RONDON, Victor (editor). Actas del V Encuentro simposio internacional de musicología, V Festival Internacional de Música renacentista y barroca americana "Misiones de Chiquitos". Santa Cruz de la Sierra. APAC.

ILLARI, Bernardo \& Ricardo ZAVADIKER 1993 Repertorio de documentos sobre música de las reducciones Jesuíticas de la Provincia del Paraguay. Chicago-Córdoba. (Texto inédito).

LÉVI-STRAUSS, Claude 1986 Mito y significado. Buenos Aires. Alianza.

LOZANO, Pedro 1874 Historia de la Conquista del Paraguay, Río de la Plata y Tucumán. Buenos Aires. Casa Editora "Imprenta popular". (5 vols.).

LEONHARDT, Carlos 1924 La música y el teatro en el tiempo de los antiguos jesuitas de la Provincia de la Compañía de Jesús del Paraguay. Estudios. Revista Mensual redactada por la Academia Literaria del Plata XXVI (enero-junio): 128-133, 203-214. Buenos Aires.

MELIÁ, Bartomeu 1986 El guaraní conquistado y reducido. Ensayos de etnohistoria. Asunción. Centro de Estudios Antropológicos, Universidad Católica Ntra. Señora de Asunción.

MÖRNER, Magnus 1999 La corona española y los foráneos en los pueblos de indios de América. Madrid. Ediciones de Cultura Hispánica/AECI.

NAWROT, Piotr. 2000. Indígenas y Cultura Musical De Las Reducciones Jesuíticas. Guaraníes, Chiquitos, Moxos. Bolivia: Editorial Verbo Divino.

PALOMERA SERREINAT, Lluís 2001 Un ritual bilingüe en las reducciones del Paraguay: el manual de Loreto (1721). Dissertatio ad Doctoratum Sacrae Liturgiae assequendum in Pontificio Instituto Liturgico. Romae. Thesis ad Lauream n. 283.

PERAMÁS, José Manuel [1791] 1946 La república de Platón y los guaraníes. Buenos Aires. Emecé Editores. 
RÍPODAS ARDANAZ, Daisy 1987 Movimientos shamánicos de liberación entre los guaraníes (1545-1660). Apartado de Teología XXIV (50): 245-275. Buenos Aires. Facultad de Teología de la Pontificia Universidad Católica Argentina.

RUIZ DE MONTOYA, Antonio 1876 Arte, Bocabulario, Tesoro y Catecismo de la Lengua Guarani. Publicado por Julio Platzmann sin alteracion alguna. Leipzig. Teubner.

RUIZ, Irma 1984 La ceremonia Nemongaraí de los Mbiá de la Provincia de Misiones. Temas de Etnomusicología 1: 51-102.

RUIZ MORENO, Aníbal 1939 La lucha antialcohólica de los jesuitas en la época colonial. Buenos Aires. Cátedra de Historia de la Medicina, Universidad de Buenos Aires.

SEPP, Anton 1973 Jardín de flores Paracuario. Buenos Aires. EUDEBA

WAISMAN, Leonardo 1998 ¿Cómo Escuchar Música Colonial Latinoamericana? Música e Investigación $1(2): 99-107$.

WAISMAN, Leonardo 2004 La contribución indígena a la música misional en Mojos (Bolivia). Memoria Americana, Cuadernos de Etnohistoria 12: 11-38.

WILDE, Guillermo 1999 La actitud guaraní ante la expulsión de los jesuitas: Ritualidad, Reciprocidad y Espacio Social. Memoria Americana, Cuadernos de Etnohistoria 8: 141-172.

WILDE, Guillermo 2003 Poderes del ritual y rituales del poder: un análisis de las celebraciones en los pueblos jesuíticos de guaraníes. Revista Española de Antropología Americana 33: 203-229.

WILDE, Guillermo 2004 El ritual como vehículo de experiencias sonoras indígenas en las doctrinas jesuíticas del Paraguay (1609-1768). Música colonial Iberoamericana: interpretaciones en torno a la práctica de ejecución y ejecución de la práctica. RONDON, Victor (editor). Actas del V Encuentro simposio internacional de musicología, V Festival Internacional de Música renacentista y barroca americana "Misiones de Chiquitos". Santa Cruz de la Sierra. APAC. 